\title{
LUANA MAGALHÃES
}

\section{Avaliação da atividade antimicrobiana de ramnolipídeos sobre}

Listeria monocytogenes

Dissertação apresentada ao Instituto de Química de São Carlos da Universidade de São Paulo para obtenção do titulo de Mestre em Química

Área de concentração: Química Orgânica e Biológica

Orientadora: Prof $^{\mathrm{a}}$ Dr. Marcia Nitschke

Exemplar revisado.

O exemplar original encontra-se disponível no Serviço de Pós Graduação do IQSC-USP.

São Carlos 
Fico pensando que, para onde quer que sua jornada leve você, sempre haverá deuses novos esperando com paciência divina - $e$ risos.

Susan M. Watkins 


\section{Agradecimentos}

Em nossa vida existem muitos momentos que nos deparamos com encruzilhadas e temos que tomar a decisão de qual caminho seguir. Estes momentos nos fazem pensar em todos os caminhos tomados até então e em todos os valores trazidos nesta trajetória. Os valores e bagagem, que nos ajudam a seguir em frente após cada decisão tomada, vêm das pessoas que nos cercam, que nos incentivam ou que servem de exemplo e nos motivam a tomar as decisões corretas. A escolha em fazer meu mestrado foi movida por muitas dessas inspirações e pela ajuda e carinho de muitos. Neste momento vejo mais uma etapa de minha vida sendo alcançada e é com muita felicidade que agradeço a todos que estiveram comigo até aqui.

Começo aqui agradecer a minha querida família, minha mãe Regina, meu pai Juvenil e minha irmã Carine que me deram a base e sempre foram a estrutura a que me apoio em todos os momentos. Quero compartilhar este trabalho com vocês, pois sempre acreditaram em mim e no meu sucesso.

Agradeço também ao Bruno meu namorado que esteve do meu lado nos meus caminhos as vezes um pouco chuvosos. Agradeço por todo o carinho, amor e confiança.

A minha orientadora Marcia Nitschke que foi de grande ajuda no momento de minha escolha pelo mestrado. Agradeço por sua postura sempre correta e sua orientação tão dedicada.

Aos meus amigos, Adriano, Amanda, Cesar, Flávia, Milene e Patrícia que sempre estão presentes que me ouvem nos momentos de desabafo e me apóiam nos momentos de decisão. Principalmente a minha amiga e companheira de laboratório Mari por tornar meu dia a dia mais divertido.

Aos Técnicos Marília e João que me ajudaram sempre que necessário.

À Prof ${ }^{a}$ Dr $^{a}$. Maria Teresa Destro (FCF-USP) por me conceder linhagens de $L$. monocytogenes para meu trabalho.

À Prof ${ }^{a} \operatorname{Dr}^{a}$. Eny Maria Vieira por disponibilizar o uso da leitora de microplacas.

Ao Profo Dr. Carlos Alberto Montanari por permitir o uso do fluorímetro para microplaca e a técnica Fabiana por me ajudar a utilizar o equipamento. 
Este trabalho é dedicado aos meus queridos pais.

Todo o carinho e amor depositado por eles me trouxeram até aqui, caminhar junto a eles é o que me faz querer seguir sempre em frente. 


\section{RESUMO}

Os ramnolipídeos $(\mathrm{RL})$ são biossurfatantes que apresentam características de grande interesse para a indústria de alimentos, tais como alta biodegradabilidade, baixa toxicidade e propriedades emulsionantes. Este trabalho teve como objetivo avaliar a atividade antimicrobiana do ramnolipídeo comercial (RL-Com - Jeneil Co.) e do ramnolipídeo produzido e purificado no Laboratório de Biotecnologia Microbiana (RL-LBM) sobre culturas de Listeria monocytogenes, através da determinação da concentração inibitória mínima (CIM) utilizando o método de microdiluição em caldo. Os valores de CIM dos RLs variaram entre $78,1 \mu \mathrm{g} \mathrm{mL}^{-1}$ e $2500 \mu \mathrm{g} \mathrm{mL}^{-1}$ sendo que a CIM predominante foi de $2500 \mu \mathrm{g} \mathrm{mL}^{-1}$. Dentre as 32 L. monocytogenes testadas $68,7 \%$ foram sensíveis ao RL-LBM e 90,6\% sensíveis ao RL-Com. O efeito do ramnolipídeo sobre $L$. monocytogenes mostrou-se predominantemente bacteriostático. $\mathrm{O} R \mathrm{R}$ aumentou a permeabilidade celular de L. monocytogenes, contudo este efeito não foi relacionado à sua atividade antimicrobiana. A interação entre os antimicrobianos RL-Com e nisina foi avaliada sobre dois isolados de $L$. monocytogenes com sensibilidades diferentes ao $\mathrm{RL}$, o $\mathrm{L} 17$ menos sensível, com CIM de $2500 \mu \mathrm{g} \mathrm{mL}^{-1}$, e o L12 mais sensível, com CIM de 156,2 $\mu \mathrm{g} \mathrm{mL}^{-1}$. O índice CIF obtido para os isolados foi de 0,078 e 0,18, para L17 e $\mathrm{L} 12$ respectivamente, caracterizando o efeito sinérgico da combinação entre $R L$ e nisina. As curvas de sobrevivência dos isolados L12 e L17 mostraram que a interação entre a nisina e o $R L$ foi bactericida em concentrações menores que as obtidas individualmente para cada antimicrobiano. Para a L12 a combinação de $78,1 \mu \mathrm{g} \mathrm{mL}^{-1}$ de $\mathrm{RL}$ e $160 \mathrm{UI} \mathrm{\textrm {mL } ^ { - 1 }}$ de nisina reduziu completamente a população em 30 min de tratamento, e para a

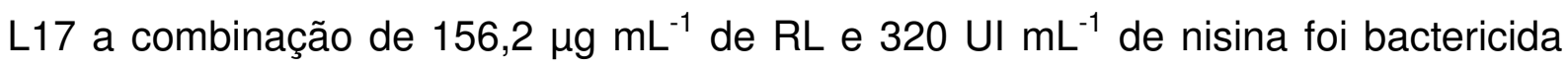
após $2 \mathrm{~h}$. Os resultados obtidos neste trabalho demonstraram que o ramnolipídeo possui potencial como agente de controle de L. monocytogenes assim como efeito sinérgico quando combinado à nisina.

Palavras-chave: atividade antimicrobiana, Listeria monocytogenes, nisina, ramnolipídeo, sinergismo. 


\begin{abstract}
The rhamnolipids ( $R L)$ are biodegradable biosurfactants which have low toxicity and surface activity properties that can be useful for food processing industries. The objective of this study was to evaluate the susceptibility of Listeria monocytogenes with two rhamnolipids products: the rhamnolipid from $P$. aeruginosa LBI that was produced and purified in the Microbial Biotechnology Laboratory (RL$\mathrm{MBL}$ ) and a commercial product (RL-Com - Jeneil Co.). Susceptibility tests were performed by the minimal inhibitory concentration (MIC) using the micro-broth dilution technique. The MIC values varied from $78.1 \mathrm{\mu g} \mathrm{mL}^{-1}$ to $2500 \mu \mathrm{g} \mathrm{mL}^{-1}$ and the 2500 $\mu \mathrm{g} \mathrm{mL} \mathrm{m}^{-1}$ concentration was the predominant value. Among the 32 tested cultures, $68.7 \%$ were susceptible to RL-MBL and $90.6 \%$ to RL-Com. Results showed that the rhamnolipid activity was primarily bacteriostatic. The $\mathrm{RL}$ increases the membrane permeability of $L$. monocytogenes, however this effect was not directly related to its antimicrobial activity. The combined effect of nisin and RL-Com was evaluated against two wild-type isolates of L. monocytogenes, L12 more sensitive (MIC 156.2 $\left.\mu \mathrm{g} \mathrm{mL} \mathrm{m}^{-1}\right)$ and $\mathrm{L} 17$ less sensitive $\left(2500 \mu \mathrm{g} \mathrm{mL}{ }^{-1}\right)$. The FIC index for the isolates were 0.18 and 0.078 for L12 and L17 respectively, indicating a particular synergistic effect. The survival curve of isolates L12 and L17 showed that the combination between nisin and $R L$ was bactericidal at lower concentration than for the individual antimicrobials. For $\mathrm{L} 12$ isolate $78.1 \mathrm{\mu g} \mathrm{mL}^{-1}$ of $\mathrm{RL}$ and $160 \mathrm{UI} \mathrm{mL}^{-1}$ of nisin eliminated the population after 30 min of incubation. The combination of $156.2 \mu \mathrm{g} \mathrm{mL}^{-1}$ of $\mathrm{RL}$ and $320 \mathrm{UI} \mathrm{mL}^{-1}$ of nisin reduced completely $\mathrm{L} 17$ population after $2 \mathrm{~h}$ of incubation. This work demonstrated the potential antimicrobial activity of rhamnolipids against $L$. monocytogenes, as well as the synergistic effect of this biosurfactant with nisin.
\end{abstract}

Keywords: antimicrobial activity, Listeria monocytogenes, nisin, rhamnolipids, synergistic effect. 


\section{LISTA DE FIGURAS}

Figura 1 - Estrutura química do mono-ramnolipídeo (a) e do di-ramnolipídeo (b) .....20 Figura 2 - Reação de redução do sal MTT de coloração amarela para o sal MTTformazam de coloração roxa ..........................................................................24

Figura 3 - Estrutura molecular do iodeto de propídio ..........................................25

Figura 4 - Representação da estrutura química da nisina ..................................26 Figura 5 - llustração da microplaca de 96 cavidades que foi utilizada para determinação da CIM para cada linhagem de L. monocytogenes, com a distribuição de cada ramnolipídeo na placa e suas concentrações em cada coluna.

Figura 6 - llustração do procedimento utilizado para determinação da CIM e da CBM

Figura 7 - Painel Checkerboard com combinações dos antimicrobianos ramnolipídeo $(\mathrm{RL})$ e nisina (Nis)

Figura 8 - Ramnolipídeo LBM antes e após a purificação...

Figura 9 - Perfil de sensibilidade de L. monocytogenes a RL-LBM e RL-Com.

Figura 10 - Estrutura molecular do composto metil 6-O-octanoil-a-Dglucopiranosídeo

Figura 11 - Efeito de concentrações crescentes de RL sobre a permeabilidade da membrana de L. monocytogenes L12 e L06. 52

Figura 12 - Modo de ação da nisina para a formação de poros na membrana plasmática. a) A nisina se aproxima da membrana plasmática, b) liga-se ao Lipídio II da membrana pelo domínio $\mathrm{N}$ terminal da nisina, c) orienta-se de forma que a parte hidrofóbica da nisina fique dentro da membrana. d) Outros complexos Nisina-Lipídio II interagem com outras moléculas de nisina formando um poro transmembrana ...55 Figura 13 - Representação da microplaca para o teste checkerboard para os isolados L12 (a) e L17 (b) utilizando a combinação do RL com nisina. Em cinza as cavidades em que houve crescimento microbiano e em branco onde não houve crescimento. Destacado em preto o valor de concentrações que foram utilizados para o cálculo do ICIF .56

Figura 14 - Curva de sobrevivência de $L$. monocytogenes $L 12$ para o tratamento com $\mathrm{RL}\left(156,2 \mu \mathrm{g} \mathrm{mL}^{-1}\right)$, nisina (320 Ul mL $\left.\mathrm{L}^{-1}\right)$, combinação de $\mathrm{RL}\left(78,1 \mu \mathrm{gL}^{-1}\right)+$ nisina $\left(160 \mathrm{UI} \mathrm{mL}^{-1}\right)$ e o controle. .59 
Figura 15 - Curva de sobrevivência de L. monocytogenes $L 17$ para o tratamento com $\mathrm{RL}\left(2500 \mu \mathrm{g} \mathrm{mL}^{-1}\right)$, nisina $\left(640 \mathrm{UI} \mathrm{mL}^{-1}\right)$, combinação de $\mathrm{RL}\left(156,2 \mu \mathrm{g} \mathrm{mL}^{-1}\right)+$ nisina $\left(320 \mathrm{UI} \mathrm{mL}^{-1}\right)$ e o controle.......................................................................60

Figura 16 - llustração do ensaio para a curva de sobrevivência de L. monocytogenes $\mathrm{L} 17$ e os tratamentos com RL $\left(2500 \mu \mathrm{gL}^{-1}\right)$, nisina (640 $\left.\mathrm{Ul} \mathrm{mL}^{-1}\right)$ e a combinação $\mathrm{RL}\left(156,2 \mu \mathrm{g} \mathrm{mL}^{-1}\right)+$ nisina $\left(320 \mathrm{UI} \mathrm{mL}^{-1}\right)$ após $24 \mathrm{~h}$ de tratamento .61 


\section{LISTA DE TABELAS}

Tabela 1 - Impacto dos patógenos que mais causam mortes por contaminação alimentar. 16

Tabela 2 - Relação dos reagentes utilizados no trabalho. 30

Tabela 3 - Relação de equipamentos e materiais utilizados no trabalho 30

Tabela 4 - Origem das culturas de Listeria monocytogenes utilizadas no trabalho...32 Tabela 5 - Valores de ICIF correspondentes a diferentes interações entre antimicrobianos

Tabela 6 - Composição da amostra de ramnolipídeo - LBM e ramnolipídeo comercial. .46

Tabela 7 - Valores de CIM e de CBM do ramnolipídeo LBM e do ramnolipídeo comercial sobre $L$. monocytogenes. .48

Tabela 8 - Percentual de linhagens sensíveis ao RL - Com e ao RL- LBM 49

Tabela 9 - CIM dos ramnolipídeos sobre os isolados L06 e L12. .51

Tabela 10 - Valores de CIM do RL-Com e da Nisina sobre os isolados L12 e L17...53 Tabela 11 - Valores de CIM dos antimicrobianos RL comercial e nisina individualmente e em combinação e índice CIF da interação dos antimicrobianos...57 Tabela 12 - Concentração bactericida mínima do $R L$ e da nisina individualmente e em combinação 


\section{SUMÁRIO}

1 INTRODUÇÃO

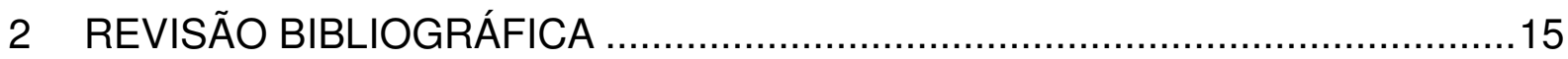

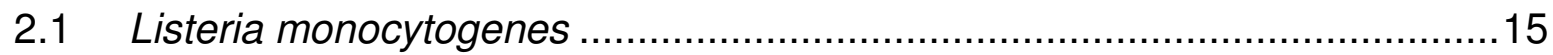

2.1.1 Características Microbiológicas ...................................................16

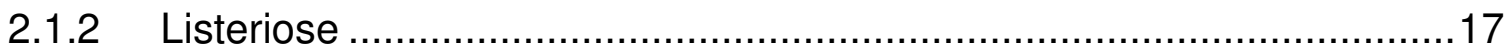

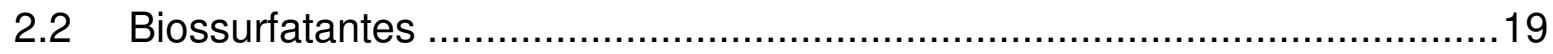

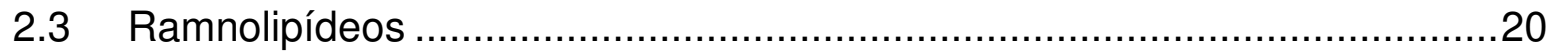

2.3.1 Atividade antimicrobiana dos Ramnolipídeos ...................................22

2.4 Métodos para Avaliação da Atividade Antimicrobiana.................................22

2.4.1 Método de difusão em ágar .........................................................23

2.4.2 Método de diluição em caldo ...........................................................23

2.5 Avaliação da integridade da membrana celular .......................................25

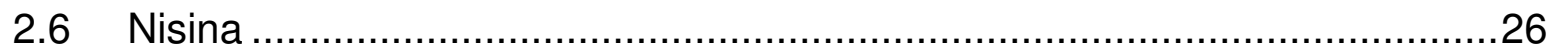

2.7 Métodos de avaliação da interação de antimicrobianos..............................28

3 OBJETIVOS

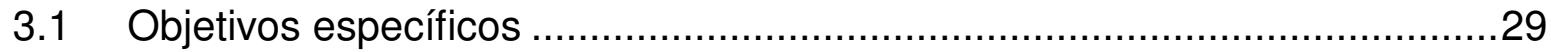

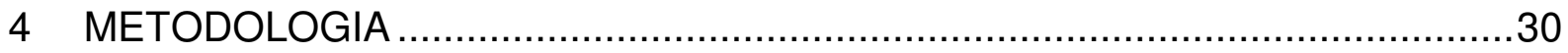

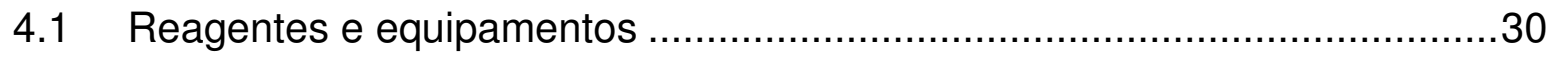

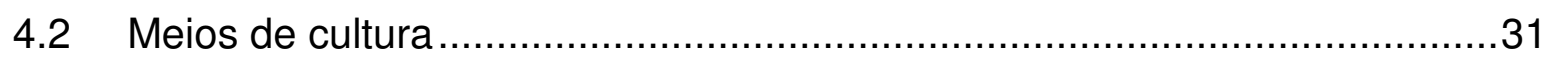

4.3 Microrganismos:

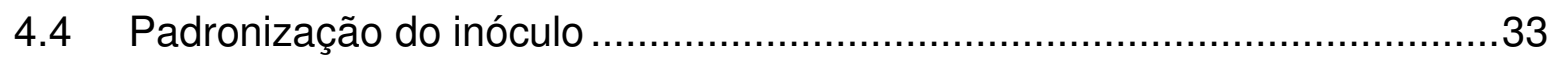

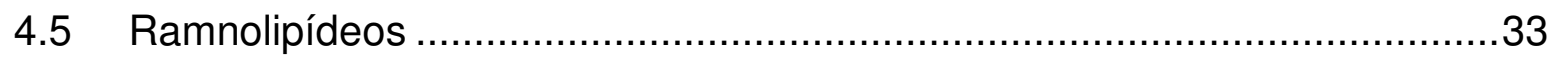

4.5.1 Purificação do ramnolipídeo …………….........................................33

4.6 Teste de atividade antimicrobiana ...........................................................

4.6.1 Preparo das soluções de ramnolipídeos...............................................34

4.6.2 Determinação da CIM .......................................................................34 


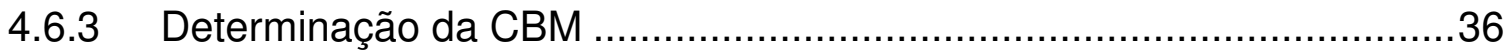

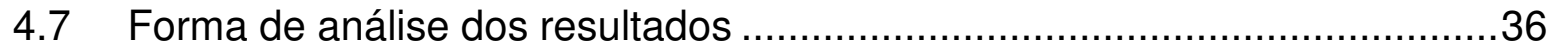

4.8 Avaliação da permeabilidade da membrana e determinação do fator de absorção de iodeto de propídio.................................................................

4.8.1 Preparo das Soluções ...................................................................

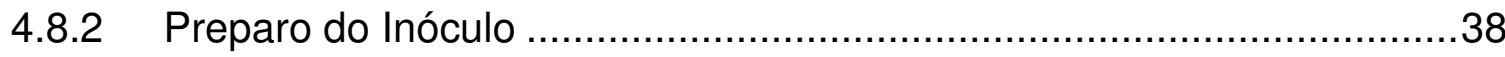

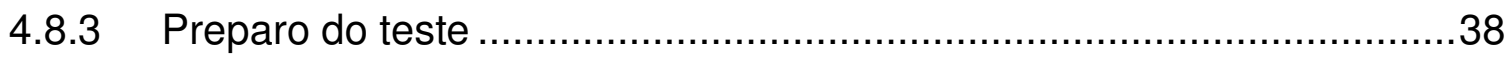

4.9 Determinação da interação antimicrobiana da nisina e ramnolipídeo ..........40

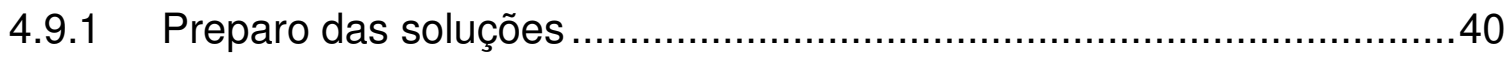

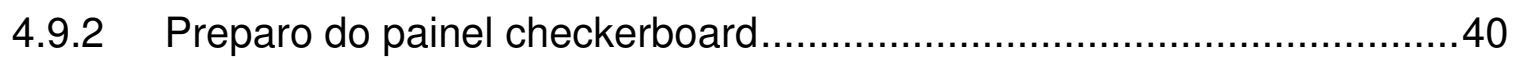

4.10 Curva de sobrevivência................................................................... 42

4.10.1 Preparo das Soluções estoque .............................................. 42

4.10.2 Procedimento da curva de sobrevivência...................................43

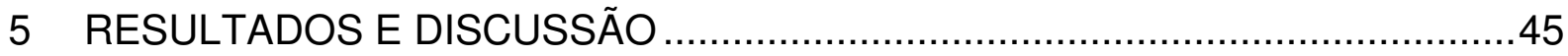

5.1 Purificação e composição dos Ramnolipídeos .........................................45

5.2 Atividade antimicrobiana dos ramnolipídeos sobre L. monocytogenes.......47

5.3 Efeito do RL sobre a permeabilidade celular de L. monocytogenes ...........51

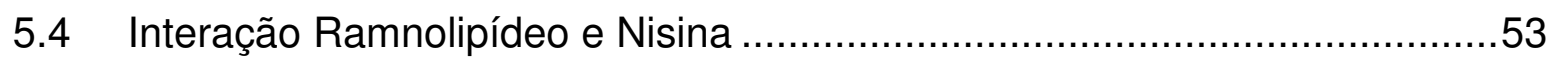

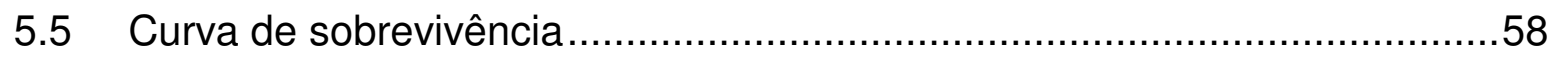

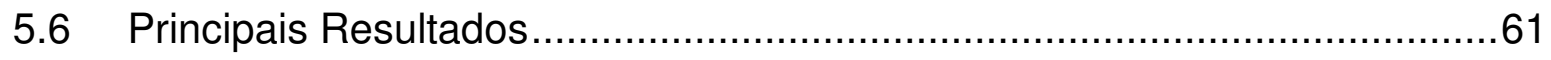

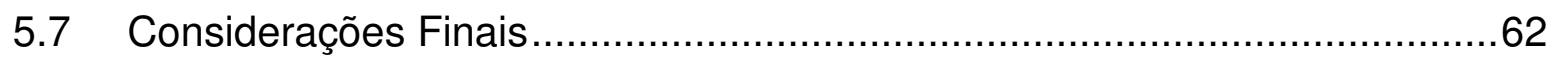

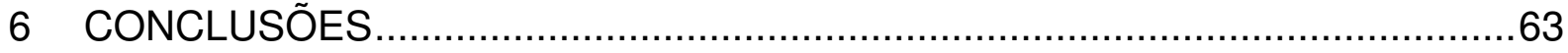

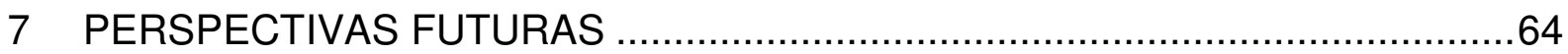




\section{INTRODUÇÃO}

Contaminações por alimentos podem causar mais de 200 diferentes doenças em seres humanos (CDC, 2012). Segundo a CDC (US Centers for Disease Control and Prevention) por ano, nos EUA, 76 milhões de pessoas são acometidas por alguma doença de origem alimentar com 325000 hospitalizações e 5000 mortes. As doenças de origem alimentar geram um gasto para os EUA de U\$10-83 bilhões por ano, relativos aos tratamentos de pacientes, custos de medicamentos, queda de produtividade entre outros danos (NYACHUBA, 2010).

Os problemas causados por contaminações alimentares trazem um grande impacto econômico e à saúde publica. São vários os fatores que contribuem para a grande ocorrência de doenças relacionadas à contaminação alimentar, como por exemplo, o crescimento populacional que gera uma grande demanda de alimentos, o grande número de pessoas que fazem suas refeições em restaurantes e a capacidade de adaptação dos microrganismos que levam ao surgimento de novos patógenos (NYACHUBA, 2010).

Listeria monocytogenes é um importante patógeno de origem alimentar causador da doença listeriose. Esta bactéria ganhou bastante destaque após a década de 1980 quando surgiram os primeiros surtos de listeriose nos EUA e Europa (McLAUCHIN, 1996). Sua ocorrência é observada em alimentos como carnes cruas, vegetais, leite e derivados, entretanto sua presença está mais fortemente relacionada a produtos processados prontos para consumo como queijos e embutidos (WHITE et al., 2002; GUERRA; BERNARDO, 2004). As contaminações em alimentos prontos para consumo são mais preocupantes, uma vez que $L$. monocytogenes pode se desenvolver mesmo em ambientes refrigerados, o que permite seu crescimento durante os períodos de estocagem destes produtos (LIU, 2008).

A listeriose pode causar sérios problemas de saúde levando ao aborto e meningite listérica. A presença de $L$. monocytogenes em alimentos representa um grande risco uma vez que o número de indivíduos susceptíveis vem crescendo com o aumento da longevidade da população (CRUZ; MARTINEZ; DESTRO, 2008, MANTILLA et al., 2007). Consequentemente, alguns países como EUA, Itália e Austrália adotaram a política de "tolerância zero" para a presença de $L$. 
monocytogenes em alimentos prontos para consumo (GUERRA; BERNARDO, 2004, FDA, 2011a)

Além disso, L. monocytogenes possui grande capacidade de adaptação, pois apresenta tolerância a altas concentrações de sais, ampla faixa de $\mathrm{pH}(\mathrm{pH} 4-9)$ e de temperatura $\left(-0,4\right.$ a $\left.45^{\circ} \mathrm{C}\right)$ e podem formar biofilmes sobre superfícies (RAY, 2004; DWORKIN et al., 2006; MØRETRØ; LANGSRUD, 2004; WHITE et al., 2002)

Apesar de serem relatados poucos casos de contaminação por $L$. monocytogenes este patógeno deve ser controlado, pois a listeriose é uma doença que em muitos casos pode ser fatal. Grupos de alto risco como pessoas com câncer AIDS, mulheres grávidas e idosos são bastante susceptíveis a doença uma vez que a $L$. monocytogenes está presente em diversos alimentos consumidos no dia a dia como queijos, presuntos e outros alimentos processados prontos para consumo (CRUZ; MARTINEZ; DESTRO, 2008).

Tendo em vista a necessidade em se produzir alimentos mais seguros e livre de L. monocytogenes é imprescindível a procura por novos preservantes para uso em alimentos (MARTÍNEZ; RODRÍGUEZ, 2005).

Os ramnolipídeos são biossurfatantes produzidos principalmente por Pseudomonas aeruginosa que apresentam excelente atividade tensoativa, biodegradabilidade e baixa toxicidade (HABA et al., 2003; NITSCHKE; COSTA; CONTIERO, 2011). A estrutura anfifílica destas moléculas permite seu uso como agentes emulsionantes em diversas aplicações industriais em formulações cosméticas, farmacêuticas e alimentos (MAIER; SOBERÓN-CHÁVEZ, 2000).

Em estudo recente, Araújo (2009) demonstrou que os ramnolipídeos produzidos por $P$. aeruginosa PA1 apresentaram atividade anti-adesiva e antimicrobiana sobre L. monocytogenes ATCC 19112. Este resultado, embora preliminar, sugere que os ramnolipídeos podem ser aplicados como agentes de controle desta bactéria, entretanto outras linhagens bacterianas e tipos de ramnolipídeos devem ser testados, para se determinar o potencial de aplicação destes compostos como agentes inibidores do patógeno.

As propriedades apresentadas pelos ramnolipídeos poderia propiciar sua incorporação em alimentos como ingredientes multi-propósito, ou seja, um ingrediente único que apresenta atividade emulsionante, antimicrobiana e antiadesiva simultaneamente, tornando este biossurfatante uma importante alternativa para o controle da L. monocytogenes principalmente em alimentos processados. 
O objetivo deste trabalho foi avaliar o potencial antimicrobiano de ramnolipídeos sobre $L$. monocytogenes através da determinação da Concentração Inibitória Mínima (CIM) e da Concentração Bactericida Mínima (CBM) utilizando diferentes linhagens isoladas e de coleção. Avaliou-se ainda o efeito da combinação dos ramnolipídeos com a nisina sobre o crescimento de Listeria monocytogenes, uma vez que a nisina é um agente antimicrobiano muito utilizado como preservante para controle deste patógeno (BENKERROUM; SANDINE, 1988). 


\section{REVISÃo BIBLIOGRÁFICA}

\subsection{Listeria monocytogenes}

A bactéria Listeria foi descrita pela primeira vez em 1926 por Murray e colaboradores que a isolaram do fígado de coelhos e suínos doentes. Contudo o primeiro caso confirmado da doença causada por esta bactéria ocorreu em 1929, quando Listeria monocytogenes foi isolada de um paciente que sofria de mononucleose (GUERRA; BERNARDO, 2004).

Somente na década de 1980 a listeriose, doença causada pela $L$. monocytogenes, foi associada ao consumo de alimentos contaminados. Nesta mesma década a Listeria monocytogenes foi classificada como um importante patógeno de origem alimentar (WHITE et al., 2002), pois foram registrados vários surtos relacionados ao consumo de alimentos contaminados na Inglaterra e EUA (McLAUCHILIN, 1996).

Apesar de apresentar baixa incidência, 2 a 5 casos por milhão de habitantes (GUERRA; BERNARDO, 2004; FARBER; PETERKIN, 1991), a listeriose é uma doença grave, pois em cerca de $30 \%$ dos casos pode levar a morte (McLAUCHILIN, 1996; LIU, 2008). Nos EUA apenas 3\% das hospitalizações, decorrentes de contaminações por patógenos alimentares, resultam em morte, dessas mortes 19\% estão relacionadas a contaminações por L. monocytogenes (Tabela 1 ), sendo a listeriose a terceira maior causa de morte por doenças deste gênero (CDC, 2011a; MEAD et al., 1999; GUERRA; BERNARDO, 2004; FARBER; PETERKIN, 1991).

A L. monocytogenes pode se desenvolver mesmo em ambientes desfavoráveis com baixas temperaturas e escassez de nutrientes. Pode ser encontrada no solo, em diferentes vegetais e no intestino de humanos e animais 0 que facilita a contaminação da água e alimentos (WHITE et al., 2002; MANTILLA et al., 2007).

Os principais alimentos que podem apresentar contaminação por $L$. monocytogenes são vegetais frescos, carne crua, leite não pasteurizado, produtos lácteos, ovos, frutos do mar, porém a incidência está mais fortemente relacionada a alimentos processados mantidos sob refrigeração (WHITE et al., 2002, GANDHI; CHIKINDAS, 2007). 
Tabela 1 - Impacto dos patógenos que mais causam mortes por contaminação alimentar

\begin{tabular}{cc}
\hline Patógenos & $\%$ morte \\
\hline Salmonella & $28 \%$ \\
Toxoplasma gondii & $24 \%$ \\
Listeria monocytogenes & $19 \%$ \\
Norovirus & $11 \%$ \\
Campylobacter ssp. & $6 \%$
\end{tabular}

(CDC, 2011a)

Em geral os surtos de listeriose estão relacionados ao consumo de alimentos processados industrialmente, pois durante o processamento, manufatura e distribuição existem vários pontos em que pode ocorrer contaminação (GUERRA; BERNARDO, 2004; WHITE et al., 2002). Entre os alimentos industrializados os produtos prontos para consumo representam maior risco, pois são armazenados por longos períodos sob refrigeração, condição esta, que permite a multiplicação da $L$. monocytogenes (GUERRA; BERNARDO, 2004).

Outro fator a ser considerado é a sua capacidade de formar biofilmes em superfícies como metal, vidro e borracha (RAY, 2004). A formação de biofilmes por L. monocytogenes a torna menos suscetível aos desinfetantes, pois nesta condição, ocorre maior resistência física devido a formação da matriz polimérica (MØRETR LANGSRUD, 2004; LIU, 2008). Os biofilmes representam um grave problema para a indústria alimentícia, pois sua presença em equipamentos e utensílios, que entram em contato com alimentos, causa riscos de contaminação (CARPENTIER; CERF, 2011).

\subsubsection{Características Microbiológicas}

L. monocytogenes é caracterizada como bastonetes, gram positivos, não esporulados, não apresentam cápsula, geralmente móveis em temperaturas moderadas $\left(20^{\circ} \mathrm{C}\right)$. Possuem flagelos peritríqueos, mas sua ocorrência se dá apenas entre 20 e $25{ }^{\circ} \mathrm{C}$, sendo que a $37{ }^{\circ} \mathrm{C}$ a presença de flagelos é incomum (DWORKIN et al., 2006). 
Metabolismo aeróbico e anaeróbico facultativo, pode se desenvolver entre $-0,4$ e $50{ }^{\circ} \mathrm{C}$ mas seu nível de crescimento ótimo se dá entre 30 e $37^{\circ} \mathrm{C}$. O pH pode estar entre 5,2 e 9. Como produto final resultante da fermentação da glicose tem-se ácido lático, ácido acético entre outros (LIU, 2008). O teste de catalase é positivo, oxidase negativo e expressam a enzima $\beta$-hemolisina e apresentam halos hemólise total quando crescem em ágar sangue. A presença desta enzima é o maior fator de virulência para este patógeno. Suas colônias são circulares brancas e semitransparentes apresentando cor levemente esverdeada quando a luz incide obliquamente (FARBER; PETERKIN, 1991).

O gênero Listeria se divide em seis espécies (Listeria grayi, Listeria innocua, Listeria ivanovii, Listeria welshimeri, Listeria seeligeri e Listeria monocytogenes), mas somente a $L$. monocytogenes e a L. ivanovii são consideradas patogênicas ao ser humano (LIU, 2008). A L. monocytogenes é classificada nos seguintes sorotipos: 1/2a, 1/2b, 1/2c, 3a, 3b, 4a, 4b, 4c, 4e, 7 (MANTILLA et al., 2007), sendo a maior parte dos casos de surtos de listeriose causada pelos sorotipos 1/2a, 1/2b e $4 b$ (FARBER; PETERKIN, 1991).

\subsubsection{Listeriose}

Listeria monocytogenes é um patógeno oportunista que infecta somente hospedeiros que apresentam condições imunológicas favoráveis (CRUZ; MARTINEZ; DESTRO, 2008; DWORKIN et al., 2006). O grupo de alto risco para a listeriose inclui pessoas com o sistema imunológico comprometido como pacientes com AIDS, câncer, diabetes, mulheres grávidas e pessoas imunocomprometidas com idade acima de 60 anos (McLAUCHILIN, 1996; LIU, 2008; EFSA, 2007).

A principal forma de contaminação por L. monocytogenes se dá pela ingestão de alimentos contaminados por este patógeno, embora existam outras vias de transmissão (McLAUCHILIN, 1996) tais como ocular, respiratória e urogenital (GUERRA; BERNARDO, 2004; McLAUCHLIN, 1996).

Há também vias de contágios interpessoais a partir do contato com aparatos hospitalares que estejam contaminados por L. monocytogenes. Esta é a causa da contaminação entre recém-nascidos com listeriose congênita e outros recémnascidos que estejam na mesma unidade hospitalar (GUERRA; BERNARDO, 2004). 
Após a contaminação por L. monocytogenes pode haver diferentes formas de manifestação da doença. Quando a contaminação ocorre pela via oral a bactéria chega ao intestino, atinge a corrente sanguínea, podendo migrar para diferentes órgãos e tecidos onde cresce e estimula o aparecimento de variados sintomas dependendo do órgão infectado (LIU, 2008; McLAUCHLIN, 1996). Dentre os sintomas da doença estão: febre e dor de cabeça, semelhantes aos sintomas de um resfriado, gastroenterites, abortos; nos casos de contaminação de fetos e em pacientes imunocomprometidos a bactéria pode atingir o sistema nervoso causando meningites e meningoencefalites (LIU, 2008, DWORKIN et al., 2006). A L. monocytogenes pode atingir a placenta de mulheres grávidas, podendo haver uma infecção transplacentária. A contaminação entre mãe e filho pode ocorrer também a partir do canal vaginal durante o parto (McLAUCHILIN, 1996; GUERRA; BERNARDO, 2004, CRUZ; MARTINEZ; DESTRO, 2008). Entre 17-24\% dos casos de listeriose incluem mulheres grávidas sendo que em $28 \%$ ocorre aborto ou nascimento prematuro (LIU, 2008).

Na década de 1980 houve muitos surtos de listeriose envolvendo o consumo de alimentos contaminados por L. monocytogenes. O principal surto ocorreu no Canadá em 1981 e foi provocado pelo consumo de repolho cru contaminado. Foi com este caso que se associou a listeriose ao consumo de alimentos. A partir desta data outros surtos envolvendo um grande número de pessoas ocorreram nos EUA, Suiça e Inglaterra (McLAUCHILIN, 1996; GUERRA; BERNARDO, 2004).

O grande número de casos de listeriose tornou a $L$. monocytogenes um importante patógeno de origem alimentar. Com o intuito de minimizar os casos da doença foram tomadas medidas de sanitização mais eficazes na indústria de alimentos para o controle deste patógeno (CDC, 2011b). Em alguns países como EUA, Itália e Austrália adotou-se ainda a política de "tolerância zero" para a $L$. monocytogenes em alimentos prontos para consumo (GUERRA; BERNARDO, 2004).

Na década de 1990 houve um declínio na incidência de listeriose tanto na Europa quanto nos EUA, todavia a partir de 2000 houve um aumento nos casos na Europa, sendo $55,6 \%$ destes reportados em pacientes com idade superior a 65 anos (EFSA, 2007).

Recentemente (setembro de 2011) foi relatado pelo FDA (U. S. Food and Drug Administration) um surto de listeriose relacionado ao consumo de melões tipo 
cantaloupe em 17 estados dos EUA. Neste surto 55 pessoas foram contaminadas e 8 morreram. A empresa Jensen Farms teve que suspender sua produção e distribuição dos melões e recolher os produtos do mercado até o término das investigações (FDA, 2011b).

Em países desenvolvidos os casos de listeriose são notificados e existem documentações sobre a incidência anual desta doença, contudo em países da África, Ásia, América do Sul e alguns países da Europa sua incidência é muito baixa (ADAK; LONG; O'BRIEN, 2002). Essa baixa incidência pode ocorrer devido a menor exposição ao contaminante ou pela falta de diagnósticos adequados e notificação dos casos (GUERRA; BERNARDO, 2004; CRUZ; MARTINEZ; DESTRO, 2008). No Brasil a listeriose é subdiagnosticada ou os casos incidentes não são documentados havendo poucas informações a respeito da incidência desta doença no país (CRUZ; MARTINEZ; DESTRO, 2008).

\subsection{Biossurfatantes}

Os biossurfatantes são uma classe de compostos, que possuem atividade tensoativa, produzidos por uma grande variedade de microrganismos. Estes compostos possuem uma parte hidrofílica composta geralmente por aminoácidos ou açúcares e uma parte hidrofóbica composta por uma cadeia hidrocarbônica ou ácido graxo. Sua característica anfifílica lhe garante grande aplicabilidade na indústria como agente tensoativo e emulsificante em formulações farmacêuticas, cosméticas e em alimentos (BANAT et al., 2010).

Estes compostos podem ser classificados por sua estrutura química ou por sua origem microbiana. Os biossurfatantes de alta massa molecular incluem polímeros de polissacarídeos, lipopolissacarídeos, proteínas e lipoproteínas, e biossurfatantes de baixa massa molecular incluem lipopeptídeos, glicolipídeos e ácidos graxos (BANAT et al., 2010).

Os biossurfatantes apresentam vantagens sobre surfatantes sintéticos por apresentarem baixa toxicidade e alta biodegradabilidade. Entretanto, seu uso não é disseminado devido aos custos elevados de produção quando comparados aos sintéticos. Estudos vêm sendo realizados para otimizar a produção destes compostos tornando-os mais atrativos para as indústrias (RODRIGUES et al., 2006). 


\subsection{Ramnolipídeos}

Os ramnolipídeos são biossurfatantes da classe dos glicolipídeos produzidos principalmente por Pseudomonas aeruginosa. São compostos anfifílicos constituídos por moléculas de ramnose na sua porção hidrofílica e por cadeias de ácidos graxos na porção hidrofóbica. São produzidos como uma mistura de homólogos que diferem entre si pelo número de ramnoses e pelo tamanho da cadeia de ácidos graxos (LANG; WULLBRANDT, 1999) (Figura 1).

Os homólogos de maior predominância nas misturas de ramnolipídeos são os mono-ramnolipídeos, formados por uma ramnose ligada a duas moléculas de ácido $\beta$-hidroxidecanóico, e os di-ramnolipídeos, formados por duas ramnoses ligadas a duas moléculas de ácido $\beta$-hidroxidecanóico (Figura 1) (NITSCHKE; COSTA; CONTIERO, 2011; LANG; WULLBRANDT, 1999).

Atualmente, com as novas tecnologias analíticas empregadas no estudo de ramnolipídeos, já foram relatadas aproximadamente 60 diferentes tipos de moléculas homólogas (ABDEL-MAWGOUD; LÉPINE; DÉZIEL, 2010).

a)

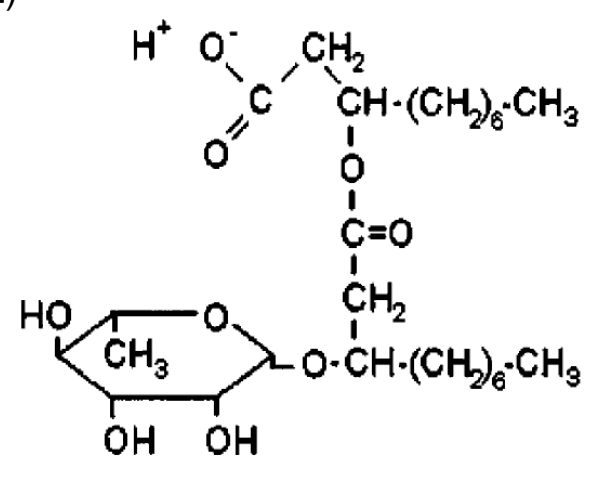

b)

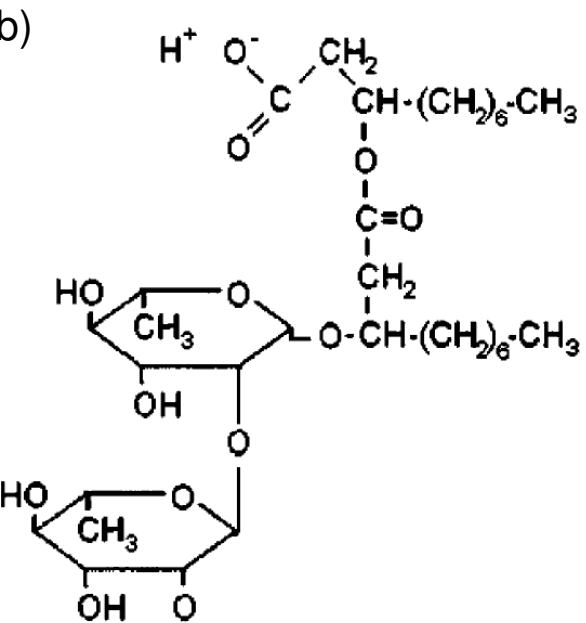

Figura 1 - Estrutura química do mono-ramnolipídeo (a) e do di-ramnolipídeo (b) (NGUYEN et al.,2008)

Este biossurfatante pode diminuir a tensão superficial da água de $72 \mathrm{mN} \mathrm{m}^{-1}$ para 20-30 mN m${ }^{-1}$ em concentrações de $10-200 \mathrm{mg} \mathrm{L}^{-1}$ e diminuir a tensão interfacial de sistemas óleo/água para valores abaixo de $1 \mathrm{mN} \mathrm{m}^{-1}$ (LANG; WULLBRANDT, 1999). Acima da concentração micelar crítica (CMC) os ramnolipídeos formam micelas, vesículas ou lamelas, contudo os valores da CMC 
podem variar segundo a composição de homólogos da mistura, sendo que já foram relatados valores entre 5-200 $\mathrm{mg} \mathrm{L}^{-1}$ (NITSCHKE; COSTA; CONTIERO, 2011)

Ainda não foram precisamente definidas as funções fisiológicas dos ramnolipídeos para $P$. aeruginosa, mas supõe-se que estejam relacionadas à sua característica anfifílica. Uma das funções atribuídas aos ramnolipídeos é a de facilitar a assimilação de substratos hidrofóbicos, como hidrocarbonetos, para sua utilização como fonte de carbono (ABDEL-MAWGOUD; LÉPINE; DÉZIEL, 2010).

Os ramnolipídeos são biossurfatantes muito conhecidos, pois apresentam características de baixa toxicidade e alta biodegradabilidade de muito interesse para a indústria especialmente na área ambiental, farmacêutica, cosmética e alimentícia (LANG; WULLBRANDT, 1999; MAIER; SOBERÓN-CHÁVEZ, 2000).

$\mathrm{Na}$ área ambiental, os ramnolipídeos podem ser utilizados na biorremediação de poluentes insolúveis, uma vez que podem auxiliar a emulsificação dos contaminantes orgânicos tornando-os pseudossolubilizados (BANAT, et al., 2010). Os ramnolipídeos causam alterações na membrana celular dos microrganismos biodegradadores tornando-as mais hidrofóbicas e, portanto, favorecendo a interação com compostos orgânicos desta natureza (MAIER; SOBERÓN-CHÁVEZ, 2000).

$\mathrm{Na}$ área de alimentos, estudos demonstraram que os ramnolipídeos apresentam atividade antiadesiva inibindo a formação de biofilmes de bactérias de importância alimentar como a Listeria monocytogenes (SINGH; CAMEOTRA, 2004; ARAÚJO et al., 2011), e também sobre outros microrganismos como Bordetella bronchiseptica (IRIE; O`TOOLE; YUK, 2005), Candida lipolytica (RUFINO et al., 2011) e Bacillus pumilus (DUSANE et al., 2010).

Apesar de sua grande aplicabilidade, os ramnolipídeos, assim como os outros biossurfatantes, possuem restrições para o uso na indústria devido ao elevado custo de produção. Para tornar este produto economicamente viável alguns autores vêm estudando a utilização de resíduos agroindustriais como substratos para a sua produção (NITSCHKE; COSTA; CONTIERO, 2010; BENINCASA et al., 2002). 


\subsubsection{Atividade antimicrobiana dos Ramnolipídeos}

Os ramnolipídeos apresentam atividade antimicrobiana sobre diversos microrganismos incluindo bactérias gram positivas, gram negativas, fungos e leveduras (HABA et al., 2003; ABALOS et al., 2001). Possuem atividade antibacteriana sobre Enterobacter aerogenes, Bacillus subtilis, Staphylococcus aureus, Serratia marcescens, Klebsiella pneumoniae com concentrações inibitórias mínimas entre 0,5 - $8 \mu \mathrm{g} \mathrm{mL} \mathrm{m}^{-1}$, além de atividade antifúngica sobre Chaetonium globosum, Penicillium funiculosum, Candida albicans (HABA et al., 2003; BENINCASA et al., 2004).

Em geral a atividade antimicrobiana dos biossurfatantes está relacionada a sua atuação sobre a membrana celular, pois suas características anfipáticas permitem interação com a bicamada fosfolipídica da membrana (HABA et al., 2003). Contudo, o mecanismo de ação dos ramnolipídeos ainda não é bem esclarecido, alguns autores propõem uma intercalação de suas moléculas com a membrana celular e subsequente destruição da mesma (LANG; WULLBRANDT, 1999).

Ortiz et al. (2006) analisaram a interação de di-ramnolipídeos com fosfolipídeos de membrana e observaram que os di-ramnolipídeos perturbam a organização da membrana e aumentam a distância entre as bicamadas, afetando assim, o funcionamento celular.

A principal dificuldade em se elucidar o mecanismo de ação dos ramnolipídeos se deve ao fato de que a $P$. aeruginosa produz uma mistura heterogênea de moléculas homólogas, e cada homólogo possui uma contribuição individual sobre a atividade antimicrobiana do produto (SÁNCHEZ et al., 2006).

\subsection{Métodos para Avaliação da Atividade Antimicrobiana}

Para avaliar a suscetibilidade de um microrganismo frente a um determinado antimicrobiano são realizados testes de atividade antimicrobiana. Estes testes são divididos em métodos de difusão e diluição (TORTORA; FUNKE; CASE, 2005). 


\subsubsection{Método de difusão em ágar}

Os métodos de difusão são os mais utilizados para a determinação da suscetibilidade microbiana (VERMA, 2007). Neste teste o microrganismo é inoculado sobre toda a superfície de um meio de cultura sólido e sobre este inóculo são colocados discos de papel, impregnados com 0 antimicrobiano em uma concentração conhecida. A droga difunde pelo ágar e caso ocorra atividade antimicrobiana sobre o microrganismo testado surgirá uma zona de inibição em torno do disco onde não haverá crescimento. Em geral quanto maior a zona de inibição mais sensível é o microrganismo ao antimicrobiano (TORTORA; FUNKE; CASE, 2005).

Uma análise quantitativa da atividade antimicrobiana de uma determinada droga pode ser obtida utilizando discos com diferentes concentrações e analisando os halos de inibição formados. O método de difusão possui ainda as vantagens de ser simples e barato, contudo apresenta a desvantagem dos resultados poderem variar de acordo com a solubilidade do antimicrobiano no ágar (VERMA, 2007, ELLOF, 1998).

\subsubsection{Método de diluição em caldo}

O método de diluição em caldo de cultura embora seja mais trabalhoso que os métodos de difusão, apresenta a vantagem de permitir a avaliação quantitativa da eficiência de um antimicrobiano. Com este teste pode-se determinar a concentração inibitória mínima (CIM), menor concentração de agente antimicrobiano capaz de inibir o crescimento microbiano, e a concentração bactericida mínima (CBM), que constitui a menor concentração do antimicrobiano que mata 99,9\% do inóculo bacteriano. O teste para a determinação da CBM permite avaliar se o antimicrobiano apresenta atividade bacteriostática ou bactericida (ABALOS et al., 2001; HABA et al., 2003; VERMA, 2007).

As técnicas de diluição são divididas em macro e microdiluição. Na macrodiluição são utilizados tubos de ensaio enquanto a microdiluição utilizam-se placas de microtitulação de 96 poços (VERMA, 2007). Em ambas as técnicas são realizadas diluições sucessivas do antimicrobiano em caldo de cultura onde é adicionado um inóculo padronizado do microrganismo. Após incubação é feita uma 
análise da turbidez do meio de cultura comparando a um padrão positivo de crescimento microbiano. A menor concentração em que não há crescimento biológico é definida como a CIM (OSTROSKY et al., 2008).

A determinação da CIM pode ser realizada utilizando indicadores como sais de resazurina e sais de tetrazólio que permitem a visualização da viabilidade celular e ajudam na leitura do teste. O sal 3-[4,5-dimetiltiazol-2-il]-2,5-difenil-brometo de tetrazólio (MTT) que é amarelo, é reduzido ao composto roxo MTT formazam pela enzima mitocondrial succinil desidrogenase que somente está presente em células viáveis (Figura 2). A alteração de cor do amarelo para o roxo permite observar quais diluições apresentaram crescimento microbiano e desta forma determinar a CIM (MOSMANN, 1983).
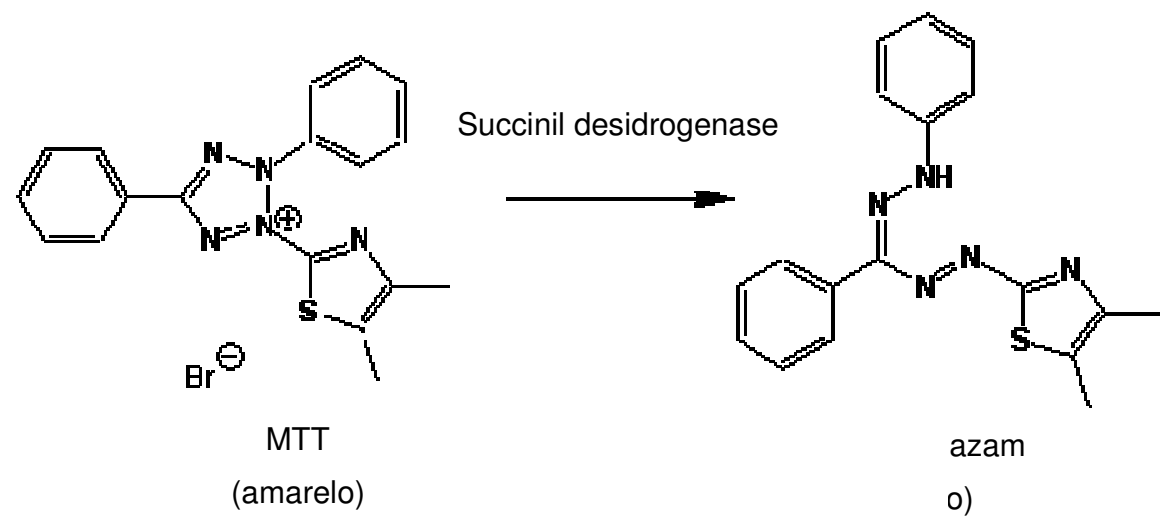

o)

Figura 2 - Reação de redução do sal MTT de coloração amarela para o sal MTT-formazam de coloração roxa

As cavidades ou os tubos que não apresentarem crescimento podem ser cultivados em meio livre da droga para a determinação da concentração bactericida mínima (TORTORA; FUNKE; CASE, 2005). A menor concentração testada em que não houver o crescimento microbiano é denominada CBM.

Quando o antimicrobiano apresenta CBM sobre uma determinada bactéria considera-se que este mata o microrganismo diretamente. Quando o antimicrobiano inibe o crescimento bacteriano, porém o teste de CBM é negativo, conclui-se que, o efeito do antimicrobiano é bacteriostático, ou seja, o antimicrobiano inibe o crescimento bacteriano e na ausência do mesmo a bactéria pode tornar a se desenvolver (TORTORA; FUNKE; CASE, 2005). 


\subsection{Avaliação da integridade da membrana celular}

A membrana plasmática é constituída principalmente de fosfolipídeos e proteínas que revestem o citoplasma celular. Os fosfolipídeos de membrana apresentam porção hidrofóbica contendo ácidos graxos e um componente hidrofílico representado pelo glicerol fosfato; esta estrutura anfipática se agrega quando em solução aquosa formando uma bicamada (MADIGAN et al., 2010; TORTORA; FUNKE; CASE, 2005).

Sua função primordial é exercer uma barreira entre a célula e o meio externo através da permeabilidade seletiva, controlando a entrada e saída de moléculas da célula. A membrana plasmática permite que o interior celular apresente composição adequada e diferente do meio externo. Além disso, a membrana está envolvida na produção de energia em células procarióticas e é local de ancoragem de diferentes proteínas (TORTORA; FUNKE; CASE, 2005).

Visto a importância da membrana celular para a integridade do microrganismo, danos a esta barreira podem levar a morte celular. Os ramnolipídeos apresentam atividade antimicrobiana sobre vários microrganismos, uma das hipóteses para o mecanismo de ação é que estes atuem sobre a membrana celular incorporando-se à bicamada lipídica e modificando sua permeabilidade (HABA et al., 2003).

O iodeto de propídio (Figura 3) é um composto fluorescente que pode ser utilizado para a detecção de danos na membrana plasmática. Este composto tem sua fluorescência aumentada quando em contato com o DNA celular, pois se intercala ao DNA formando um complexo que produz em intenso sinal de fluorescência. Este corante somente consegue penetrar na célula se houver danos na membrana, pois é um composto polar e altamente solúvel em meio aquoso, quando a célula está intacta ela o expulsa para fora (DENGLER et al., 1995).

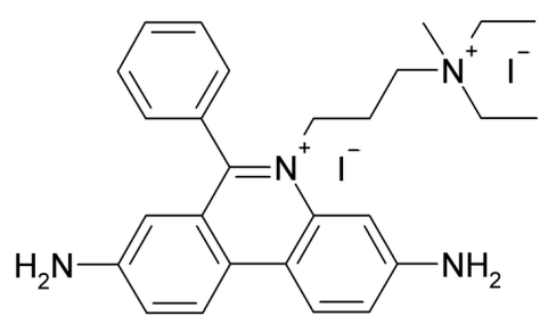

Figura 3 - Estrutura molecular do iodeto de propídio 
Quando ligado ao DNA o iodeto de propídio apresenta absorção em 530 nm e emissão em 620 nm (DENGLER et al., 1995). Monitorando a intensidade da fluorescência emitida pelo composto em contato com as células é possível avaliar o grau de permeabilidade celular que será tanto maior quanto maior for sua fluorescência (GARCIA-GONZALEZ et al., 2010).

\subsection{Nisina}

Bacteriocinas são peptídeos com atividade antimicrobiana produzidos por bactérias (SCHULZ et al., 2003). A nisina é uma bacteriocina produzida por algumas linhagens de Lactococcus lactis conhecida desde 1928, e que apresenta atividade antimicrobiana sobre vários microrganismos sendo atualmente utilizada como conservante em alimentos (JACK; TAGG; RAY, 1995; ABEE et al., 1994; SCHULZ et al., 2003)

As bacteriocinas são divididas em quatro grupos que são classificados de acordo com suas características bioquímicas e pelo seu espectro de ação antimicrobiana (SCHULZ et al., 2003). A nisina pertence a classe I das bacteriocinas, também chamada de lantiobióticos, que se caracterizam como pequenos peptídeos (19-38 aminoácidos), que possuem em sua estrutura resíduos de lantionina (CLEVELAND et al., 2001; McAULIFFE; ROSS; HILL, 1996). Este resíduo incomum forma ligação tioeter entre aminoácidos formando anéis na estrutura do peptídeo (BREUKINK; DE KRUIJFF, 2006)

A nisina é um peptídeo catiônico e hidrofóbico formado por 34 aminoácidos com cinco anéis de lantionina (Figura 4), é resistente a altas temperaturas e é pouco solúvel em meio moderadamente alcalino (MELO; SOARES; GONÇALVES, 2005; GUIOTTO et al., 2003).

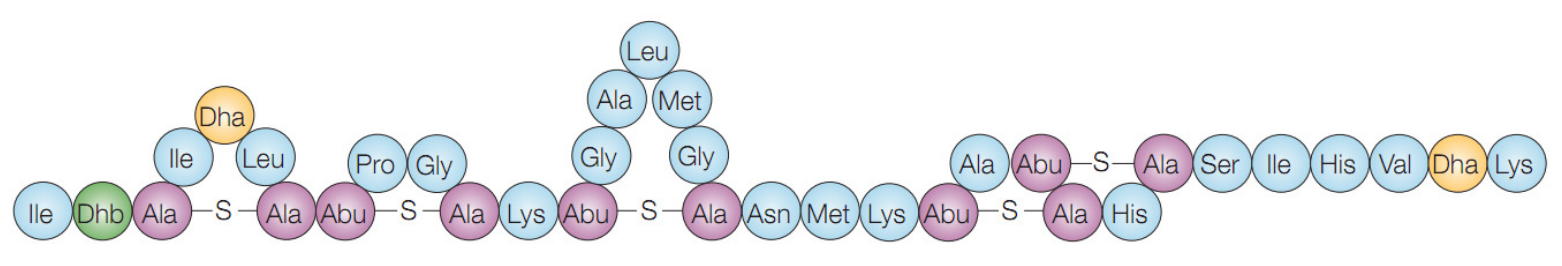

Figura 4 - Representação da estrutura química da nisina (COTTER; HILL; ROSS; 2005) 
Seu uso como preservante em alimentos é aprovado pela World Health Organization (WHO) e é utilizada em mais de 50 países principalmente em produtos lácteos (ESTEBAN; PALOP, 2011). O uso da nisina no Brasil é permitido na concentração máxima de $12,5 \mathrm{mg} \mathrm{kg}^{-1}$ de produto, podendo ser usado em todos os tipos de queijos e em produtos cárneos (DE MARTINIS; ALVES; FRANCO, 2002).

Desde 1988 o FDA reconhece a nisina como um preservante seguro para 0 consumo humano sendo classificada como uma substância GRAS (generally recognized as safe) (MELO; SOARES; GONÇALVES, 2005; JACK; TAGG; RAY, 1995).

Seu espectro de ação antimicrobiana se restringe a bactérias gram positivas, porém é ativa sobre uma grande variedade de bactérias como Lactococcus, Streptococcus, Staphylococcus, e também sobre importantes patógenos alimentares como Listeria e esporos de Clostridium (McAULIFFE; ROS; HILL, 2001)

Quando em contato com as células microbianas a nisina forma poros que permitem o efluxo de compostos de baixa massa molecular como cátions e aminoácidos (RUHR; SAHL, 1985; ABEE et al., 1994). Este efluxo leva uma alteração no gradiente de concentração de $\mathrm{H}^{+}(\Delta \mathrm{pH})$ e no potencial de membrana $(\Delta \psi)$ que leva a um colapso da força próton motiva (FPM) celular (SCHULZ et al., 2003).

A força próton motiva é formada a partir de um gradiente de $\mathrm{pH}$ dentro e fora da célula que gera uma energia potencial que permite a célula a síntese de ATP. Um colapso na FPM leva a morte celular pela falta de energia requerida nas atividades celulares (McAULIFFE; ROS; HILL, 2001).

O modo como a nisina forma poros na membrana plasmática ainda não é bem elucidado (EPAND; VOGEL, 1999); acredita-se que por ser um composto catiônico a nisina estabeleça interações eletrostáticas com os lipídeos de membrana negativamente carregados e desta forma ocorre o primeiro contato com a célula. Após se ligar a membrana plasmática a parte hidrofóbica da nisina se insere na bicamada lipídica. Os monômeros de nisina então se agregam na bicamada formando um poro (CLEVELAND et al., 2001; SCHULZ et al., 2003).

O potencial antimicrobiano da nisina varia de acordo com a composição lipídica da membrana da espécie alvo, como a nisina possui cargas positivas a presença de lipídeos carregados negativamente favorece a ligação da bacteriocina à 
célula tornando-a mais sensível a ação deste antimicrobiano (CLEVELAND et al., 2001).

A atividade antimicrobiana do ramnolipídeo também está relacionada a sua capacidade de interagir com a membrana plasmática (HABA et al., 2003), seu uso combinado a nisina pode aumentar o espectro antimicrobiano de ambos (ESTEBAN; PALOP, 2011).

O sinergismo de dois antimicrobianos ocorre quando o efeito das substâncias combinadas é melhor que o desempenho individual sobre um determinado microrganismo (ESTEBAN; PALOP, 2011). O efeito sinérgico entre a nisina e o ramnolipídeo pode diminuir a dosagem dos mesmos para um efeito inibitório equivalente.

\subsection{Métodos de avaliação da interação de antimicrobianos}

O uso combinado de antimicrobianos representa uma boa forma de potencializar o efeito de duas drogas seja pelo surgimento de resistência do microrganismo a um dos antimicrobianos ou para diminuir a dosagem utilizada (BERENBAUM, 1989).

A interação entre antimicrobianos pode resultar em efeitos sinérgicos, antagônicos ou indiferentes. Para determinar o tipo de interação existem vários testes, mas o método de microdiluição checkerboard é o mais utilizado (MELETIADIS et al., 2010). Neste teste são feitas diluições dos dois antimicrobianos nos dois eixos de uma microplaca de 96 poços de forma que todas as combinações das diluições sejam testadas (SINGH et al., 2000).

Com o método de microdiluição checkerboard obtém-se o índice de concentração inibitória fracionária (ICIF) da interação dos antimicrobianos (SINGH et al., 2000). O índice CIF classifica o tipo de interação dos antimicrobianos, quando o valor do ICIF é $\leq 0,5$ considera-se que a interação foi sinérgica, quando $>0,5$ e $\leq 4$ considera-se que a interação é indiferente e quando $>4$ a interação entre os dois antimicrobianos é antagônica (VERMA, 2007). Estudos de sobrevivência utilizando a combinação dos antimicrobianos trazem ainda informações sobre o comportamento cinético da interação (MACKAY; MILNE; GOULD, 2000).

O índice ICIF é calculado através da somatória dos CIFs individuais que são determinados pela razão entre a CIM do antimicrobiano na combinação e a CIM do antimicrobiano individualmente (VERMA, 2007). 


\section{OBJETIVOS}

Determinar o potencial antimicrobiano de ramnolipídeos produzidos por $P$. aeruginosa sobre linhagens de Listeria monocytogenes.

\subsection{Objetivos específicos}

- Determinar a concentração inibitória mínima e a concentração bactericida mínima dos ramnolipídeos sobre as linhagens de L. monocytogenes.

- Avaliar a ação do ramnolipídeo sobre a permeabilidade celular da $L$. monocytogenes.

- Avaliar a interação entre o ramnolipídeo e a nisina no controle de $L$. monocytogenes. 


\section{METODOLOGIA}

\subsection{Reagentes e equipamentos}

Os reagentes e equipamentos utilizados no trabalho estão listados nas Tabelas 2 e 3.

Tabela 2 - Relação dos reagentes utilizados no trabalho

\begin{tabular}{lll}
\hline Reagente & Pureza & Marca \\
\hline Ágar triptona de soja & & Acumedia \\
Caldo triptona de soja & & Acumedia \\
Extrato de levedura & & Merck \\
Cloreto de sódio P. A. & $99,0 \%$ & Synth \\
Álcool metílico P. A. & $99,8 \%$ & Quemis \\
Brometo de tiazolil azul de tetrazolio & $98,0 \%$ & Sigma Aldrich \\
lodeto de propídio & $94,0 \%$ & Sigma Aldrich \\
Ramnolipídeo comercial JBR599 & $99,0 \%$ & Jeneil Co. \\
Nisina comercial & $2,5 \%$ & Silver Elephant \\
\hline
\end{tabular}

Tabela 3 - Relação de equipamentos e materiais utilizados no trabalho

\begin{tabular}{lll}
\hline Equipamento/ Material & Modelo & Marca \\
\hline Autoclave vertical & AV 50 & Phoenix \\
Microcentrífuga & Mini spin & Eppendorf \\
Agitador rotatório (Shaker) & MAXQ6000 & Thermo Scientific \\
Cabine de segurança biológica & Bioprotector 12 & Veco \\
Leitora de microplaca & TP-Reader & Thermoplate \\
Espectofotômetro UV-Vis & Genesys 10 UV & Thermo Scientific \\
Agitador de tubos tipo vortex & AV & Sieger
\end{tabular}




\begin{tabular}{lll} 
Equipamento/ Material & Modelo & Marca \\
\hline Rotaevaporador & RV basic & IKA \\
Fluorímetro para microplaca & Synergy HT & Biotek \\
Placa de microtitulação de poliestireno & Kartell \\
com 96 poços esterilizada & \\
Resina Amberlite XAD-2 & Sigma Aldrich \\
\hline
\end{tabular}

\subsection{Meios de cultura}

Utilizou-se caldo TSYE, preparado a partir de $30 \mathrm{~g}$ de caldo triptona de soja adicionado de $6 \mathrm{~g}$ de extrato de levedura, dissolvidos em $1000 \mathrm{~mL}$ de água destilada, com pH ajustado para 7,3 \pm 0,2. O meio sólido utilizado foi o ágar extrato de levedura triptona de soja (TSYEA), com a proporção de $40 \mathrm{~g}$ de meio e $6 \mathrm{~g}$ de extrato de levedura dissolvidos em $1000 \mathrm{~mL}$ de água destilada (ARAÚJO, 2009). Os meios de cultura foram esterilizados em autoclave a $121^{\circ} \mathrm{C}$ por 20 minutos.

\subsection{Microrganismos:}

Foram utilizadas 32 culturas de L. monocytogenes dentre elas 5 cepas de coleção e 28 isolados selvagens como descrito na Tabela 4.

As linhagens foram armazenadas em freezer a $-20^{\circ} \mathrm{C}$ em caldo extrato de levedura triptona de soja (TSYEB) adicionado de 10\% de glicerol. Cada teste de atividade antimicrobiana foi realizado a partir de uma cultura armazenada a $-20^{\circ} \mathrm{C}$. 
Tabela 4 - Origem das culturas de Listeria monocytogenes utilizadas no trabalho

\begin{tabular}{|c|c|c|}
\hline Código & Local de isolamento & Origem \\
\hline L01 & piso da câmara fria (abatedouro de aves) & \multirow{9}{*}{ FCF, USP } \\
\hline L02 & parede da sala de corte (abatedouro de aves) & \\
\hline L03 & carrinho da sala de corte (abatedouro de aves) & \\
\hline L04 & carcaça de frango (abatedouro de aves) & \\
\hline L06 & tesoura da sala de corte (abatedouro de aves) & \\
\hline L07 & $\begin{array}{c}\text { caixa onde se depositam as vísceras } \\
\text { (abatedouro de aves) }\end{array}$ & \\
\hline L08 & peito de frango (abatedouro de aves) & \\
\hline L09 & mão do manipulador (abatedouro de aves) & \\
\hline L10 & isolado clínico (abatedouro de aves) & \\
\hline L11 & piso da indústria de laticínios & UFV, MG \\
\hline L12 & queijo artesanal & UFPel, RS \\
\hline L13 & queijo minas frescal & \multirow{4}{*}{ Embrapa gado de leite } \\
\hline L14 & queijo minas frescal & \\
\hline L15 & queijo minas frescal & \\
\hline L16 & queijo minas frescal & \\
\hline L17 & gancho de nória (abatedouro de aves ) & \multirow{12}{*}{ FCF, USP } \\
\hline L18 & tesoura (abatedouro de aves) & \\
\hline L19 & piso (abatedouro de aves) & \\
\hline L20 & área interna da canaleta (abatedouro de aves) & \\
\hline L21 & pão de queijo congelado & \\
\hline L22 & queijo gouda & \\
\hline L23 & linguiça toscana & \\
\hline L24 & queijo parmesão ralado & \\
\hline L25 & queijo minas & \\
\hline L26 & carne moída & \\
\hline L27 & Presunto & \\
\hline L28 & Salsicha & \\
\hline
\end{tabular}

ATCC 7644

ATCC 15313

ATCC 19122

Coleção

ATCC 19117

SCOTT A 


\subsection{Padronização do inóculo}

As culturas foram inoculadas em placa de TSYEA a partir do estoque a $-20^{\circ} \mathrm{C}$ e incubadas por $24 \mathrm{~h}$ a $37^{\circ} \mathrm{C}$. Com o auxílio de uma alça esterilizada, algumas colônias da cultura de 24 horas foram selecionadas e diluídas em solução salina ( $\mathrm{NaCl} 0,86 \%$ ) até uma concentração de aproximadamente $10^{8} \mathrm{UFC} / \mathrm{mL}$, utilizando-se como referência o padrão 0,5 da escala de McFarland ( $1 \mathrm{~mL}$ de cloreto de bário $\left(\mathrm{BaCl}_{2}\right)$ a $1 \%+99 \mathrm{~mL}$ de ácido sulfúrico $\left(\mathrm{H}_{2} \mathrm{SO}_{4}\right)$ a $\left.1 \%\right)$. (WOODS; WASHINGTON, 1995).

\subsection{Ramnolipídeos}

Foram testados os seguintes ramnolipídeos:

- RL-LBM: Ramnolipídeo obtido de P. aeruginosa LBI produzido segundo metodologia descrita por Nitschke et al. (2005) e purificado no Laboratório de Biotecnologia Microbiana (RL-LBM), como descrito na subseção 4.5.1.

- RL-Com: Ramnolipídeo comercial JBR599 Jeneil Biosurfactant Co. com 99,0\% de pureza foi utilizado como referência.

\subsubsection{Purificação do ramnolipídeo}

Para purificar o ramnolipídeo produzido no Laboratório de Biotecnologia Microbiana foi utilizada a resina Amberlite XAD-2, que é uma resina polimérica adsorvente de poliestireno utilizada para separar compostos orgânicos solúveis dispersos em meio aquoso. O procedimento utilizado foi descrito por Irie et al. (2005).

Inicialmente a resina foi hidratada pela adição de metanol suficiente para cobrir deixando-a em repouso por $15 \mathrm{~min}$. O metanol foi retirado e em seguida foi adicionado água destilada, mantendo em repouso por $10 \mathrm{~min}$. A água foi retirada e a resina armazenada em tampão fosfato $\left(0,1 \mathrm{M} \mathrm{KH}_{2} \mathrm{PO}_{4}\right.$ e $\left.0,1 \mathrm{M} \mathrm{K}_{2} \mathrm{HPO}_{4}\right) \mathrm{pH}$ 6,1 em geladeira.

Para a purificação do ramnolipídeo foram adicionados $25 \mathrm{~mL}$ de uma solução $1 \%$ de ramnolipídeo bruto ao mesmo volume de resina, a mistura foi mantida sob agitação (150 rpm) em agitador rotatório por $12 \mathrm{~h}$ a $37^{\circ} \mathrm{C}$. Em seguida o 
sobrenadante foi removido com o auxílio de um sistema de filtração com funil de Buchner. A resina foi lavada 3 vezes com água destilada para retirar os resíduos.

Para recuperar o ramnolipídeo a resina foi transferida para um béquer com 25 $\mathrm{mL}$ de metanol, a mistura foi mantida sobre agitação por 15 min e depois filtrada. Este processo foi repetido por 3 vezes para se retirar todo o ramnolipídeo. O extrato metanólico obtido, contendo os ramnolipídeos, foi concentrado em rotaevaporador à vácuo.

\subsection{Teste de atividade antimicrobiana}

Foram realizados testes para determinação da concentração inibitória mínima (CIM) dos biossurfatantes frente às linhagens de L. monocytogenes utilizando-se a técnica de microdiluição em caldo segundo metodologia modificada metodologia modificada estabelecida pela Clinical and Laboratory Standards Institute CLSI M7-A6 2003 (WOODS; WASHINGTON, 1995). Foram realizados também testes para determinação da concentração bactericida mínima (CBM).

\subsubsection{Preparo das soluções de ramnolipídeos}

As amostras de ramnolipídeos foram preparadas, inicialmente na concentração de $5000 \mu \mathrm{g} \mathrm{mL}^{-1}$ em água destilada e filtradas em filtro 0,22 $\mu \mathrm{m}$. As soluções foram distribuídas através de diluições sucessivas em placas de microtitulação de 96 cavidades.

\subsubsection{Determinação da CIM}

Todas as cavidades da placa foram primeiramente adicionadas de $100 \mu \mathrm{L}$ de caldo de cultivo TSYE. Em seguida $100 \mu \mathrm{L}$ de amostra contendo ramnolipídeos foram adicionados nas 8 cavidades da primeira coluna (1) da placa, sendo de A-D preenchidas com o RL-LBM e de E-H preenchidas com RL-Com, como mostra a Figura 5. A diluição da solução de ramnolipídeo $\left(5000 \mu \mathrm{g} \mathrm{mL}{ }^{-1}\right)$ com o meio de cultura na primeira coluna resulta em uma concentração igual a $2500 \mu \mathrm{g} \mathrm{mL}^{-1}$, para ambas as amostras de ramnolipídeos. Após homogeneização com micropipeta, 100 $\mu \mathrm{L}$ da amostra da coluna 1 foram transferidas para coluna 2 resultando em uma 
diluição de1250 $\mathrm{g} \mathrm{mL}^{-1}$, e assim sucessivamente até a coluna 10 . A coluna 11 foi utilizada como controle positivo de crescimento contendo o caldo de cultura e o inóculo bacteriano, e a coluna 12 foi utilizada como controle negativo contendo apenas o caldo de cultura.

A todas as cavidades, exceto à coluna 12, foram adicionados $10 \mu \mathrm{L}$ de inóculo de $L$. monocytogenes padronizado na concentração $10^{8} \mathrm{UFC} \mathrm{ml}^{-1}$. A placa de microtitulação foi fechada e incubada a $37^{\circ} \mathrm{C}$ por 24 horas.

Após o período de incubação foi feita uma avaliação visual do crescimento microbiano, nas cavidades em que não foi constatado o crescimento foram realizados testes para determinar a concentração bactericida mínima (CBM). Para confirmação da avaliação visual realizou-se leitura da densidade ótica a $610 \mathrm{~nm}$ em cada cavidade, utilizando-se leitora de microplaca.

A cada cavidade da placa foi adicionado $20 \mu \mathrm{L}$ de corante brometo de tetrazolium (MTT - $1 \mathrm{mg} \mathrm{mL}^{-1}$ ) que indica a atividade metabólica quando sua cor passa do amarelo para o roxo. A CIM foi determinada como a menor concentração capaz de inibir o crescimento das bactérias em relação ao controle positivo. Cada bactéria foi testada com os dois ramnolipídeos em microplacas separadas e os ensaios foram realizados com no mínimo três repetições independentes.

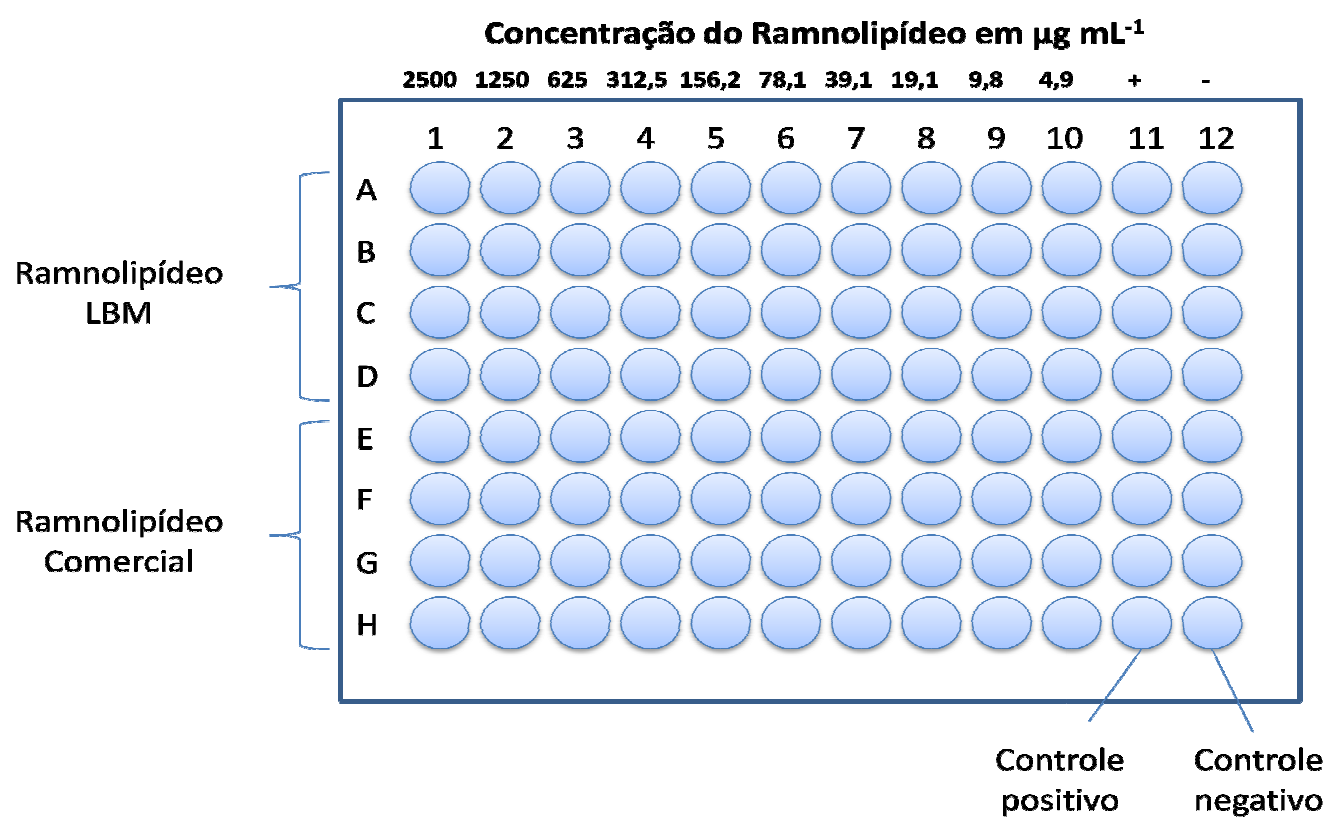

Figura 5 - Ilustração da microplaca de 96 cavidades que foi utilizada para determinação da CIM para cada linhagem de L. monocytogenes, com a distribuição de cada ramnolipídeo na placa e suas concentrações em cada coluna. 


\subsubsection{Determinação da CBM}

A análise da CBM foi realizada para as concentrações dos ramnolipídeos que não apresentaram crescimento no teste de CIM. Com auxílio de uma alça de inoculação, transferiu-se uma alíquota do meio das cavidades em que não houve crescimento microbiano para uma placa de TSYEA incubando-se a $37^{\circ} \mathrm{C}$ por $24 \mathrm{~h}$.

À menor concentração que não apresentou crescimento microbiano na placa foi designada como a CBM. Nos casos em que todas as concentrações testadas apresentaram crescimento bacteriano determinou-se que o efeito do antimicrobiano foi bacteriostático para a linhagem testada.

\subsection{Forma de análise dos resultados}

Os ensaios de atividade antimicrobiana foram realizados em quadruplicata e com no mínimo três repetições independentes. Todos os testes foram comparados com controles positivos de crescimento (cultura inoculada sem tratamento) assim como controles negativos (meio sem inóculo). A atividade antimicrobiana foi avaliada através da concentração inibitória mínima e da concentração bactericida mínima para cada bactéria e cada ramnolipídeo testado. Os resultados foram expressos como a moda de pelo menos três repetições independentes. 


\section{3}

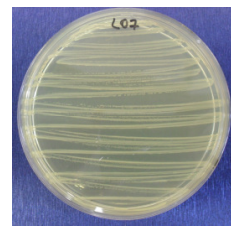

Algumas colônias de um inóculo de 24h de crescimento são dispersas em solução salina $0,86 \%$

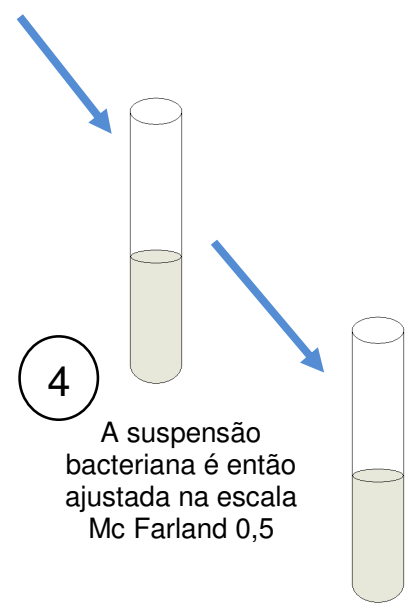
justada na escala Mc Farland 0,5

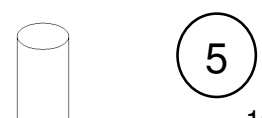

$10 \mu \mathrm{L}$ do inóculo é adicionado nas colunas 1 - 11

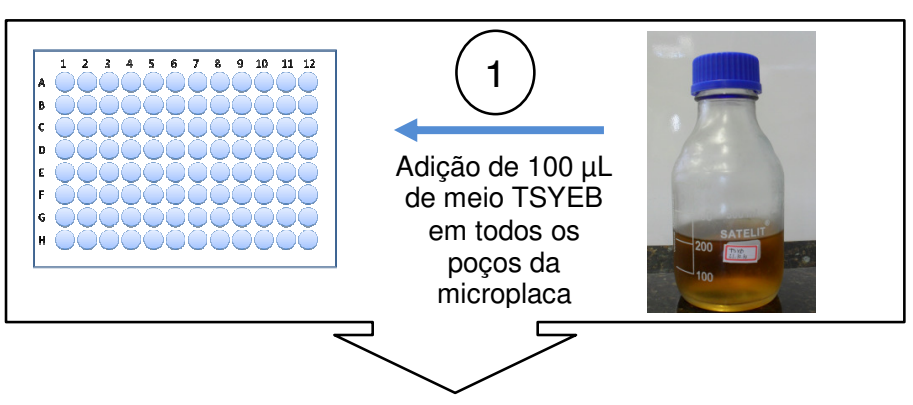

\section{กกนกกนกกร}

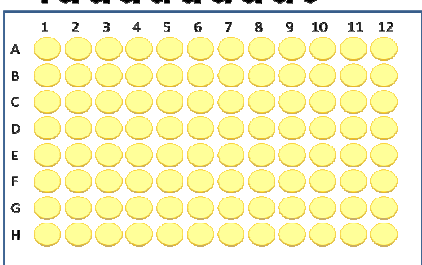

2

Adição de $100 \mu \mathrm{L}$ do Ramnolipídeo à primeira coluna com sucessivas diluições até a coluna 10
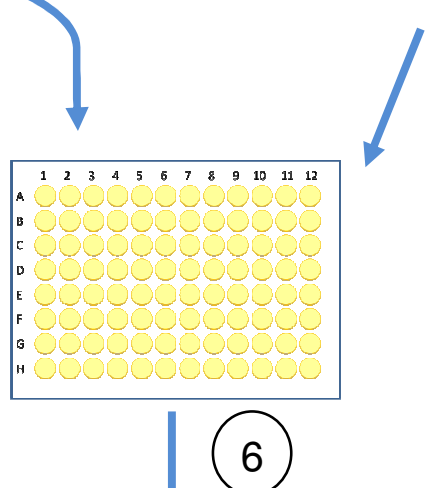

Determinação da CBM

7

Os poços sem crescimento são inoculados em TSYEA e incubados por $24 \mathrm{~h}$ à $37^{\circ} \mathrm{C}$

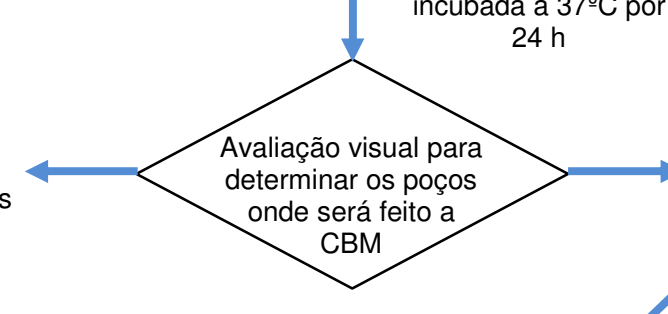

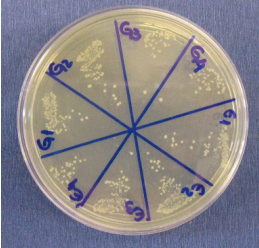

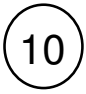

Determinação da CIM pela comparação da coloração com os controles positivos e negativos

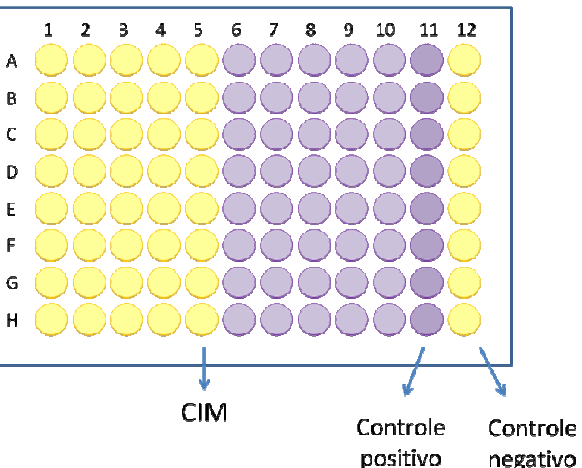

(9)

Adição de $20 \mu \mathrm{L}$ de corante MTT em todos os poços

Figura 6 - Ilustração do procedimento utilizado para determinação da CIM e da CBM 


\subsection{Avaliação da permeabilidade da membrana e determinação do fator de absorção de iodeto de propídio}

Para avaliar o efeito dos ramnolipídeos sobre a permeabilidade da membrana celular da L. monocytogenes foi utilizada a metodologia descrita por GarciaGonzalez et al. (2010) com o uso do corante iodeto de propídio.

Foi avaliada a ação do ramnolipídeo LBM e o ramnolipídeo comercial sobre as linhagens de L. monocytogenes L06 e L12, sendo a L12, com CIM de 156,2 $\mathrm{gg} \mathrm{mL}^{-1}$ para ambos os RLs e a L06 resistente. Foram testadas as mesmas concentrações de $R L$ utilizadas no teste da CIM (4,9 a $\left.2500 \mu \mathrm{g} \mathrm{mL}^{-1}\right)$.

\subsubsection{Preparo das Soluções}

- Solução de tampão fosfato ( $5 \mathrm{mM} \mathrm{KH}_{2} \mathrm{PO}_{4}$ e 5 mM Na $\left.2 \mathrm{HPO}_{4} .2 \mathrm{H}_{2} \mathrm{O}\right)$ com pH 7,2.

- Solução de iodeto de propídio $30 \mu \mathrm{M}$ preparada em tampão fosfato e armazenada em local escuro a $4^{\circ} \mathrm{C}$.

- Solução estoque de ramnolipídeo comercial $10000 \mu \mathrm{g} \mathrm{mL} \mathrm{m}^{-1}$ preparada em tampão fosfato e armazenada a $4^{\circ} \mathrm{C}$.

- Solução estoque de ramnolipídeo LBM $10000 \mu \mathrm{g} \mathrm{mL} \mathrm{m}^{-1}$ preparada em tampão fosfato e armazenada a $4^{\circ} \mathrm{C}$.

\subsubsection{Preparo do Inóculo}

O inóculo foi preparado em caldo TSYE, após $24 \mathrm{~h}$ a $37^{\circ} \mathrm{C}$, a suspensão bacteriana obtida foi centrifugada 10000 rpm. A massa bacteriana foi separada, lavada e ressuspendida em tampão fosfato.

A suspensão bacteriana foi ajustada na escala Mc Farland 0,5 que corresponde $10^{8}$ UFC $\mathrm{mL}^{-1}$.

\subsubsection{Preparo do teste}

O teste foi realizado em uma microplaca escura de 96 cavidades. Cada linhagem de L. monocytogenes foi testada com os dois RLs separadamente, as 
concentrações de cada $R L$ utilizadas foram as mesmas utilizadas no teste de CIM e variaram de 4,9- $2500 \mu \mathrm{g} \mathrm{mL}^{-1}$.

Foram adicionados $50 \mu \mathrm{L}$ de tampão fosfato nas cavidades da microplaca com sucessivas diluições dos ramnolipídeos em concentrações finais que variaram de 4,9 a $2500 \mu \mathrm{g} \mathrm{mL}^{-1}$. Adicionou-se a solução de iodeto de propídio $30 \mu \mathrm{M}$ em uma razão 1:1 (v/v) obtendo uma concentração final de $15 \mu \mathrm{M}$, em seguida $10 \mu \mathrm{L}$ do inóculo padronizado na escala Mc Farland 0,5, obtendo uma concentração final de aproximadamente $10^{7}$ UFC $\mathrm{mL}^{-1}$. O preparo do branco e dos controles estão descritos a seguir:

\section{Branco:}

- $50 \mu \mathrm{L}$ de RL com concentração $2 x$ a concentração final desejada $+50 \mu \mathrm{L}$ de tampão + $10 \mu \mathrm{L}$ do inóculo

\section{Controles:}

1) $110 \mu \mathrm{L}$ de tampão;

2) $100 \mu \mathrm{L}$ de tampão $+10 \mu \mathrm{L}$ de inóculo

3) $60 \mu \mathrm{L}$ de tampão $+50 \mu \mathrm{L}$ de solução de iodeto de propídio $30 \mu \mathrm{M}$

4) $50 \mu \mathrm{L}$ de tampão $+50 \mu \mathrm{L}$ de solução de iodeto de propídio $30 \mu \mathrm{M}+10 \mu \mathrm{L}$ de inóculo

Logo após a adição do inóculo foram realizadas medidas da fluorescência de cada cavidade em um fluorímetro para microplacas com filtros de excitação e de emissão de $532 \mathrm{~nm}$ e $600 \mathrm{~nm}$ respectivamente.

Para o cálculo do fator de absorção do iodeto de propídio (PI) foi utilizada a seguinte equação:

Fator de absorção de iodeto de propídio =

$$
\frac{F(\text { diluição } R L+\text { inóculo }+P I)-F(\text { diluição } R L+\text { inóculo })}{F(\text { Tampão fosfato }+P I)-F(\text { Tampão fosfato })}
$$




\subsection{Determinação da interação antimicrobiana da nisina e ramnolipídeo}

Para determinar o efeito da interação antimicrobiana da nisina e do ramnolipídeo foi utilizado o método microdiluição checkerboard como no protocolo descrito por Verma (2007). Foi avaliada a interação da nisina (Silver Elephant) com o ramnolipídeo comercial (Jeneil Co.) sobre as linhagens L12 e L17.

Neste teste foram preparadas combinações de diferentes concentrações dos dois antimicrobianos e determinou-se o ICIF a partir da menor combinação de concentrações em que houve inibição do crescimento bacteriano.

\subsubsection{Preparo das soluções}

- Foram preparadas duas soluções estoque de ramnolipídeo uma com $5000 \mu \mathrm{g} \mathrm{mL}^{-1}$ e outra com $10000 \mu \mathrm{g} \mathrm{mL}^{-1}$

-A solução de nisina comercial foi preparada em solução de $\mathrm{HCl} 0,02 \mathrm{M}$ na concentração de $2560 \mathrm{UI} \mathrm{mL}^{-1}$.

- As soluções foram filtradas em filtro $0,22 \mu \mathrm{m}$

- Para o teste com a linhagem L12 foram testadas combinações de ramnolipídeo que variaram de 4,9 a $625 \mathrm{\mu g} \mathrm{mL}^{-1}$ com as concentrações de nisina que variaram de $10 \mathrm{a}$ $640 \mathrm{UI} \mathrm{mL}^{-1}$.

- Para o teste com a linhagem L17 foram testadas combinações de ramnolipídeo que variaram de 9,8 a $2500 \mu \mathrm{g} \mathrm{mL}^{-1}$ com as concentrações de nisina que variaram de 10 a $640 \mathrm{UI} \mathrm{mL}^{-1}$.

\subsubsection{Preparo do painel checkerboard}

Inicialmente foi determinada a CIM do ramnolipídeo e da nisina sobre as linhagens L12 e L17 em teste isolado, seguindo a metodologia descrita na subseção 4.6.2.

Em seguida foi montado o painel checkerboard como mostrado na Figura 7. Para fazer as combinações dos antimicrobianos foram preparados dois painéis (duas microplacas separadas): 


\section{Painel 1:}

- Foi adicionado $100 \mu \mathrm{L}$ de caldo TSYE nas colunas 11 e 12.

- Foi adicionado $50 \mu \mathrm{L}$ de caldo TSYE nas colunas 1-10

- Foram feitas sucessivas diluições do ramnolipídeo da coluna 10 a 2

- Foi adicionado 50 $\mu \mathrm{L}$ da linha B1 a B8 do painel-2 na respectiva linha do painel 1. Este passo foi repetido para as linhas $\mathrm{C} \mathrm{a} \mathrm{H}$.

\section{Painel 2:}

-Foi adicionado 100 $\mathrm{LL}$ de caldo de cultura TSYE nas cavidades da microplaca.

-Foi adicionado $100 \mu \mathrm{L}$ da solução estoque de Nisina nas cavidades $\mathrm{H} 1-\mathrm{H} 8$ e foram feitas diluições de $\mathrm{H}$ a B.

No painel 1 foi adicionado $10 \mu \mathrm{L}$ do inóculo bacteriano, padronizado na escala 0,5 Mc Farland, nas colunas 1-8 e na coluna 11 (controle positivo), a coluna 12 foi o controle negativo.

\begin{tabular}{|c|c|c|c|c|c|c|c|c|c|c|c|}
\hline 1 & 2 & 3 & 4 & 5 & 6 & 7 & 8 & 9 & 10 & 11 & 12 \\
\hline A & $\begin{array}{c}1 / 32 \mathrm{CIM} \\
\mathrm{RL}\end{array}$ & $\begin{array}{c}1 / 16 \text { CIM } \\
\mathrm{RL}\end{array}$ & $\begin{array}{c}1 / 8 \mathrm{CIM} \\
\mathrm{RL}\end{array}$ & $\begin{array}{c}1 /{ }^{1} \mathrm{CIM} \\
\mathrm{RL}\end{array}$ & $\begin{array}{c}1 / 2 \mathrm{CIM} \\
\mathrm{RL}\end{array}$ & $\begin{array}{c}\mathrm{CIM} \\
\mathrm{RL}\end{array}$ & $\begin{array}{c}\text { 2CIM } \\
\text { RL }\end{array}$ & & & \multirow{8}{*}{$\begin{array}{l}\stackrel{0}{2} \\
\frac{1}{0} \\
\frac{0}{0} \\
\frac{0}{0} \\
\frac{0}{0} \\
0 \\
0\end{array}$} & \multirow{8}{*}{ 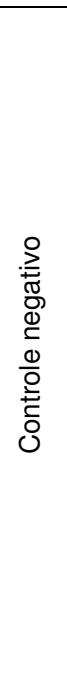 } \\
\hline $\begin{array}{c}1 / 32 \mathrm{CIM} \\
\text { Nis }\end{array}$ & & & & & & & & & & & \\
\hline $\begin{array}{c}1 / 16 \text { CIM } \\
\text { Nis }\end{array}$ & & & & & & & & & & & \\
\hline $\begin{array}{cc} & 1 / 8 \mathrm{CIM} \\
\mathrm{Nis}\end{array}$ & & & \multicolumn{3}{|c|}{ Combinação dos } & & & & & & \\
\hline \begin{tabular}{c|c}
$\mathbf{E}$ & $1 / 4 \mathrm{CIM}$ \\
$\mathrm{Nis}$
\end{tabular} & & & \multicolumn{3}{|c|}{ antimicrobianos } & & & & & & \\
\hline $\begin{array}{c}1 / 2 \text { CIM } \\
\text { Nis }\end{array}$ & & & & & & & & & & & \\
\hline $\begin{array}{l}\mathrm{CIM} \\
\mathrm{Nis}\end{array}$ & & & & & & & & & & & \\
\hline $\begin{array}{c}2 \mathrm{CIM} \\
\mathrm{Nis}\end{array}$ & & & & & & & & & & & \\
\hline
\end{tabular}

Figura 7 - Painel Checkerboard com combinações dos antimicrobianos ramnolipídeo (RL) e nisina (Nis)

A microplaca foi incubada a $3^{\circ} \mathrm{C}$ por $24 \mathrm{~h}$, posteriormente adicionou-se $20 \mu \mathrm{L}$ do corante MTT $0,1 \%$ para visualizar as cavidades em que houve crescimento bacteriano. 
Para avaliar o tipo de interação entre os antimicrobianos foi determinado o índice de concentração inibitória fracionada (ICIF) que é o somatório das concentrações fracionadas de cada antimicrobiano (eq 2).

$$
\begin{aligned}
& I C I F=C I F_{R L}+C I F_{\text {nisina }} \\
& I C I F=\frac{(C I M \text { do RL na combinação })}{(\text { CIM do RL })}+\frac{(C I M \text { da Nisina na combinação })}{(\text { CIM da Nisina })}
\end{aligned}
$$

A partir do índice CIF obtido foi avaliado o tipo de interação segundo a classificação descrita na Tabela 5

Tabela 5 - Valores de ICIF correspondentes a diferentes interações entre antimicrobianos

\begin{tabular}{cc}
\hline Interação & ICIF \\
\hline Sinergismo & CIF $\leq 0,5$ \\
Indiferente & $0,5<$ CIF $\leq 4$ \\
Antagônica & $\mathrm{CIF}>4$ \\
\hline (VERMA, 2007) &
\end{tabular}

\subsection{Curva de sobrevivência}

Para avaliar o crescimento bacteriano na presença de nisina e ramnolipídeo foram construídas curvas de sobrevivência bacteriana comparando-se 0 comportamento em relação aos antimicrobianos isoladamente e em combinação (VERMA, 2007).

\subsubsection{Preparo das Soluções estoque}

Para as curvas utilizando os antimicrobianos isolados foram preparadas soluções com concentração 100 vezes maior que o valor da CIM para a bactéria avaliada. Para a curva com a combinação foram feitas diluições destas soluções para obter a concentração final desejada. 


\section{Teste com o isolado L12}

Foi preparada uma solução aquosa de ramnolipídeo $15620 \mu \mathrm{g} \mathrm{mL} \mathrm{m}^{-1}$ e uma solução de nisina $32000 \mathrm{UI} \mathrm{mL}^{-1}$ em $\mathrm{HCl}$ 0,02 M.

\section{Teste com o isolado L17}

Foi preparada uma solução aquosa de ramnolipídeo $250 \mathrm{mg} \mathrm{mL}^{-1}$ e uma

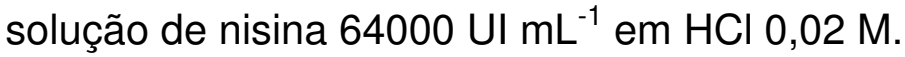

\subsubsection{Procedimento da curva de sobrevivência}

\section{Testes individuais dos antimicrobianos:}

a) 9,9 mL de caldo TSYE foram adicionados em um tubo de ensaio.

b) adicionou-se $100 \mu \mathrm{L}$ da solução estoque do antimicrobiano ( $R \mathrm{~L}$ ou nisina) agitando-se em vortex.

c) no tubo controle foi adicionado $10 \mathrm{~mL}$ de caldo TSYE.

d) $1 \mathrm{~mL}$ do inóculo padronizado a $10^{8}$ UFC mL-1 (conforme descrito na subseção 4.4) foi adicionado em cada tubo e agitado em vortex.

e) Uma alíquota de $100 \mu \mathrm{L}$ foi retirada para a contagem do número de células viáveis no tempo zero utilizando-se a técnica de diluição sucessiva conforme descrito nos itens f-i.

f) Foram colocados $900 \mu \mathrm{L}$ de solução salina 0,86\% em 7 tubos tipo eppendorf.

g) Foi adicionado ao primeiro tubo $100 \mu \mathrm{L}$ da alíquota, após homogeneização foram retirados $100 \mu \mathrm{L}$ e transferidos para o tubo seguinte. Este passo foi repetido 7 vezes para obter diluições da amostra de $10^{-1}$ a $10^{-7}$.

h) $15 \mu \mathrm{L}$ de cada diluição foram colocados sobre uma placa com meio TSYEA. As gotas foram depositadas com o auxílio de uma micropipeta.

i) As placas com as gotas foram incubadas a $37^{\circ} \mathrm{C}$ por 24 horas.

j) Este procedimento foi realizado nos tempos $30 \mathrm{~min}, 1 \mathrm{~h}, 2 \mathrm{~h}, 4 \mathrm{~h}, 8 \mathrm{~h}, 12 \mathrm{~h}$ e $24 \mathrm{~h}$ de incubação.

j) Após contagem, o número de colônias foi multiplicado pelo fator de diluição obtendo-se o valor de UFC $\mathrm{mL}^{-1}$. 


\section{Teste de interação dos antimicrobianos}

a) 9,8 $\mathrm{mL}$ de caldo de cultura TSYE foram adicionados em um tubo de ensaio.

b) Adicionou-se $100 \mu \mathrm{L}$ de cada solução estoque dos antimicrobianos, misturando em vortex.

c) Foi adicionado $10 \mathrm{~mL}$ de caldo de cultura TSYE no tubo controle.

d) Foram realizados os mesmos procedimentos dos itens d-j descritos para os testes individuais dos antimicrobianos. 


\section{RESULTADOS E DISCUSSÃO}

\subsection{Purificação e composição dos Ramnolipídeos}

Após purificação, o ramnolipídeo produzido no Laboratório de Biotecnologia Microbiana apresentou coloração mais clara e aspecto gelatinoso, como mostra a Figura 8. O aspecto mais límpido evidencia que o processo de purificação foi satisfatório para retirada de parte das impurezas presentes no produto bruto, que poderiam interferir na atividade antimicrobiana do RL.

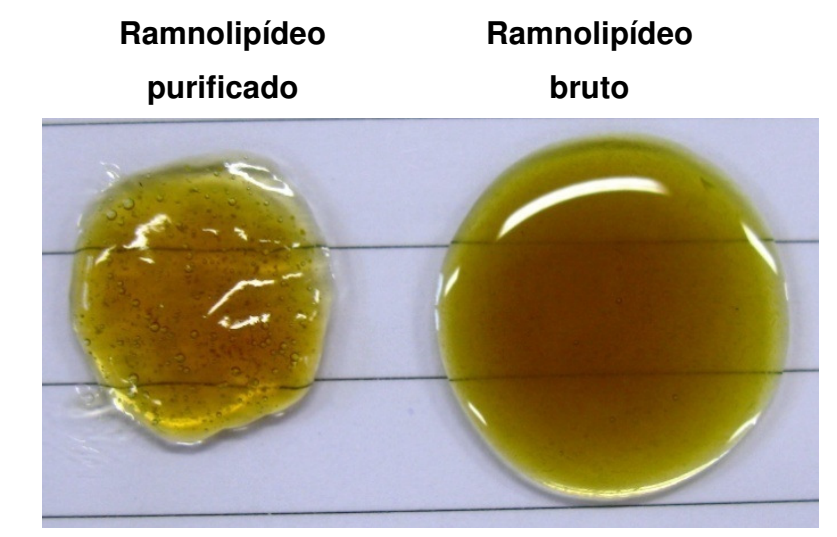

Figura 8 - Ramnolipídeo LBM antes e após a purificação

A composição de homólogos do ramnolipídeo LBM purificado e do ramnolipídeo comercial JBR599 (Jeneil Co. - EUA) foi analisada por cromatografia líquida de alta eficiência / espectrometria de massas utilizando a coluna de fase reversa Zorbax C8 segundo a metodologia descrita por Déziel et al. (1999).

O RL-LBM e o RL-Com apresentaram como componentes majoritários os homólogos mono $\left(\mathrm{RhaC}_{10} \mathrm{C}_{10}\right)$ e di-ramnolipídeo $\left(\mathrm{RhaRhaC}_{10} \mathrm{C}_{10}\right)$ como mostra a Tabela 6. Em relação a pureza dos produtos, o ramnolipídeo comercial possui 99,0\% de pureza enquanto que o RL-LBM 60,2\%. 
Tabela 6 - Composição da amostra de ramnolipídeo - LBM e ramnolipídeo comercial.

\begin{tabular}{|c|c|c|}
\hline \multirow[b]{2}{*}{ Homólogos } & \multicolumn{2}{|c|}{ Concentração (\%) } \\
\hline & Ramnolipídeo LBM & Ramnolipídeo Comercial \\
\hline $\mathrm{RhaC}_{10} \mathrm{C}_{8}$ & 1,81 & 5,28 \\
\hline $\mathrm{RhaC}_{10} \mathrm{C}_{10}$ & 35,39 & 37,67 \\
\hline $\mathrm{RhaC}_{10} \mathrm{C}_{12}$ & 1,98 & 3,53 \\
\hline $\operatorname{RhaC}_{10} \mathrm{C}_{10: 1}$ & 0,78 & 0,00 \\
\hline $\operatorname{RhaC}_{10} \mathrm{C}_{12: 1}$ & 3,72 & 3,55 \\
\hline $\operatorname{RhaC}_{12} \mathrm{C}_{12: 1}$ & 0,09 & 0,19 \\
\hline RhaRhaC $_{10} \mathrm{C}_{8}$ & 3,57 & 4,33 \\
\hline RhaRhaC $_{10} \mathrm{C}_{10}$ & 43,7 & 33,14 \\
\hline RhaRhaC $_{10} \mathrm{C}_{12}$ & 4,2 & 4,22 \\
\hline RhaRhaC $_{12} \mathrm{C}_{12}$ & 0,13 & 0,10 \\
\hline RhaRhaC $_{10} \mathrm{C}_{10: 1}$ & 0,79 & 0,00 \\
\hline RhaRhaC $_{10} \mathrm{C}_{12: 1}$ & 3,54 & 1,88 \\
\hline RhaRhaC $_{12} \mathrm{C}_{12: 1}$ & 0,25 & 0,27 \\
\hline
\end{tabular}

A composição da mistura de homólogos que compõem o ramnolipídeo está relacionada com a linhagem de $P$. aeruginosa utilizada, com a fonte de carbono e com as condições de cultivo empregadas (ABDEL-MAWGOUD; LÉPINE; DÉZIEL, 2010). Os RLs utilizados neste trabalho apresentam diferentes composições, o RLLBM tem como principal componente o di-ramnolipídeo (43,7\%) e o RL-Com o mono-ramnolipídeo $(37,67 \%)$ (Tabela 6).

Déziel et al. (1999) relataram que o RL produzido por $P$. aeruginosa 57RP, cultivada em meio contendo manitol, apresentou como componentes majoritários os di-ramnolipídeos RhaRhaC ${ }_{10} \mathrm{C}_{10}(56,95 \%)$ e RhaRha- $\mathrm{C}_{10} \mathrm{C}_{8}(11,3 \%)$.

O RL-LBM foi produzido a partir da $P$. aeruginosa LBI utilizando óleo de soja como fonte de carbono. Benincasa et al. (2002) também descreveram a produção de ramnolipídeos por $P$. aeruginosa LBI em fermentador de 2 litros utilizando como fonte de carbono resíduos do refino de óleo de soja (soapstock). A análise de composição do $R L$ revelou a presença de $28,9 \%$ de di-ramnolipídeo e $23,4 \%$ de mono-ramnolipídeo. Estes dados demonstram que para uma mesma linhagem, alterações na fonte de carbono e nas condições de cultivo, originaram RLs com diferente composição de homólogos. 
A composição e distribuição de homólogos presentes no RL é um fator importante a ser considerado, uma vez que cada homólogo pode contribuir de forma diferenciada para as propriedades do produto (ABALOS et al., 2001).

\subsection{Atividade antimicrobiana dos ramnolipídeos sobre $L$. monocytogenes}

Os valores de CIM e de CBM obtidos com os dois ramnolipídeos (RL-Com e RL-LBM) sobre as culturas de L. monocytogenes avaliadas são mostrados na Tabela 7.

Os valores de CIM do ramnolipídeo LBM e do ramnolipídeo comercial variaram entre 78,1 e $2500 \mu \mathrm{g} \mathrm{mL} \mathrm{m}^{-1}$, destacando-se que sua ação foi predominantemente bacteriostática, pois apenas 4 linhagens apresentaram CBM para as concentrações testadas.

Dentre as 32 linhagens $68,7 \%$ foram sensíveis ao RL-LBM e 90,6\% foram sensíveis ao RL-Com (Tabela 8), este resultado demonstra que ambos RLs apresentaram potencial antimicrobiano sobre L. monocytogenes. O RL - Com foi mais efetivo na inibição do crescimento de $L$. monocytogenes do que o RL - LBM, essa diferença de atividade antimicrobiana pode estar relacionada à diferença na composição de homólogos dos RLs e também pela presença de impurezas no RLLBM que podem ter influenciado na técnica de determinação dos valores de CIM. 
Tabela 7 - Valores de CIM e de CBM do ramnolipídeo LBM e do ramnolipídeo comercial sobre $L$. monocytogenes

\begin{tabular}{|c|c|c|c|c|}
\hline \multirow{2}{*}{ L. monocytogenes } & \multicolumn{2}{|c|}{ Ramnolipídeo LBM } & \multicolumn{2}{|c|}{ Ramnolipídeo Comercial } \\
\hline & $\mathrm{CIM}\left(\mu \mathrm{g} \mathrm{mL}{ }^{-1}\right)$ & $\mathrm{CBM}\left(\mu \mathrm{g} \mathrm{mL}^{-1}\right)$ & $\operatorname{CIM}\left(\mu g \mathrm{~mL}^{-1}\right)$ & $\mathrm{CBM}\left(\mu \mathrm{g} \mathrm{mL}^{-1}\right)$ \\
\hline L01 & 1250 & $>2500$ & 312,5 & $>2500$ \\
\hline L02 & 78,1 & $>2500$ & 78,1 & $>2500$ \\
\hline L03 & 2500 & $>2500$ & 312,5 & $>2500$ \\
\hline L04 & 156,2 & $>2500$ & 156,2 & $>2500$ \\
\hline L06 & $>2500$ & $>2500$ & $>2500$ & $>2500$ \\
\hline L07 & $>2500$ & $>2500$ & 2500 & $>2500$ \\
\hline L08 & 2500 & $>2500$ & 156,2 & 312,5 \\
\hline L09 & 2500 & $>2500$ & 156,2 & $>2500$ \\
\hline L10 & 2500 & $>2500$ & 2500 & $>2500$ \\
\hline L11 & $>2500$ & $>2500$ & $>2500$ & $>2500$ \\
\hline L12 & 156,2 & $>2500$ & 156,2 & 156,2 \\
\hline L13 & 312,5 & $>2500$ & 156,2 & $>2500$ \\
\hline L14 & 625 & $>2500$ & 312,5 & $>2500$ \\
\hline L15 & 1250 & $>2500$ & 625 & $>2500$ \\
\hline L16 & 1250 & $>2500$ & 2500 & $>2500$ \\
\hline ATCC 19117 & 2500 & $>2500$ & 2500 & $>2500$ \\
\hline ATCC 15313 & 2500 & $>2500$ & 2500 & $>2500$ \\
\hline SCOTT A & 2500 & $>2500$ & 2500 & $>2500$ \\
\hline ATCC 19112 & 625 & $>2500$ & 156,2 & 2500 \\
\hline ATCC 7644 & 1250 & $>2500$ & 625 & $>2500$ \\
\hline L17 & $>2500$ & $>2500$ & 2500 & $>2500$ \\
\hline L18 & 2500 & $>2500$ & 625 & $>2500$ \\
\hline L19 & $>2500$ & $>2500$ & 2500 & $>2500$ \\
\hline L20 & 625 & $>2500$ & 625 & 1250 \\
\hline L21 & $>2500$ & $>2500$ & $>2500$ & $>2500$ \\
\hline L22 & 2500 & $>2500$ & 312,5 & $>2500$ \\
\hline L23 & $>2500$ & $>2500$ & 2500 & $>2500$ \\
\hline L24 & $>2500$ & $>2500$ & 2500 & $>2500$ \\
\hline L25 & $>2500$ & $>2500$ & 2500 & $>2500$ \\
\hline L26 & $>2500$ & $>2500$ & 2500 & $>2500$ \\
\hline L27 & 2500 & $>2500$ & 156,2 & $>2500$ \\
\hline L28 & 2500 & $>2500$ & 312,5 & $>2500$ \\
\hline
\end{tabular}


Tabela 8 - Percentual de linhagens sensíveis ao RL - Com e ao RL- LBM

\begin{tabular}{|c|c|c|c|c|}
\hline \multirow{2}{*}{ Ramnolipídeo } & \multicolumn{2}{|c|}{ Sensível } & \multicolumn{2}{|c|}{ Resistente } \\
\hline & $\mathrm{N}^{*}$ & $\%$ & $\mathrm{~N}$ & $\%$ \\
\hline$R L-L B M$ & 22 & 68,7 & 10 & 31,3 \\
\hline $\mathrm{RL}-\mathrm{Com}$ & 29 & 90,6 & 3 & 9,4 \\
\hline
\end{tabular}

O isolado mais sensível ao ramnolipídeo foi o L02 que apresentou CIM de $78,1 \mu \mathrm{gL}^{-1}$ para ambos os RLs, porém a CIM predominante para as outras linhagens foi de $2500 \mu \mathrm{g} \mathrm{mL}^{-1}$, como mostra a Figura 9.

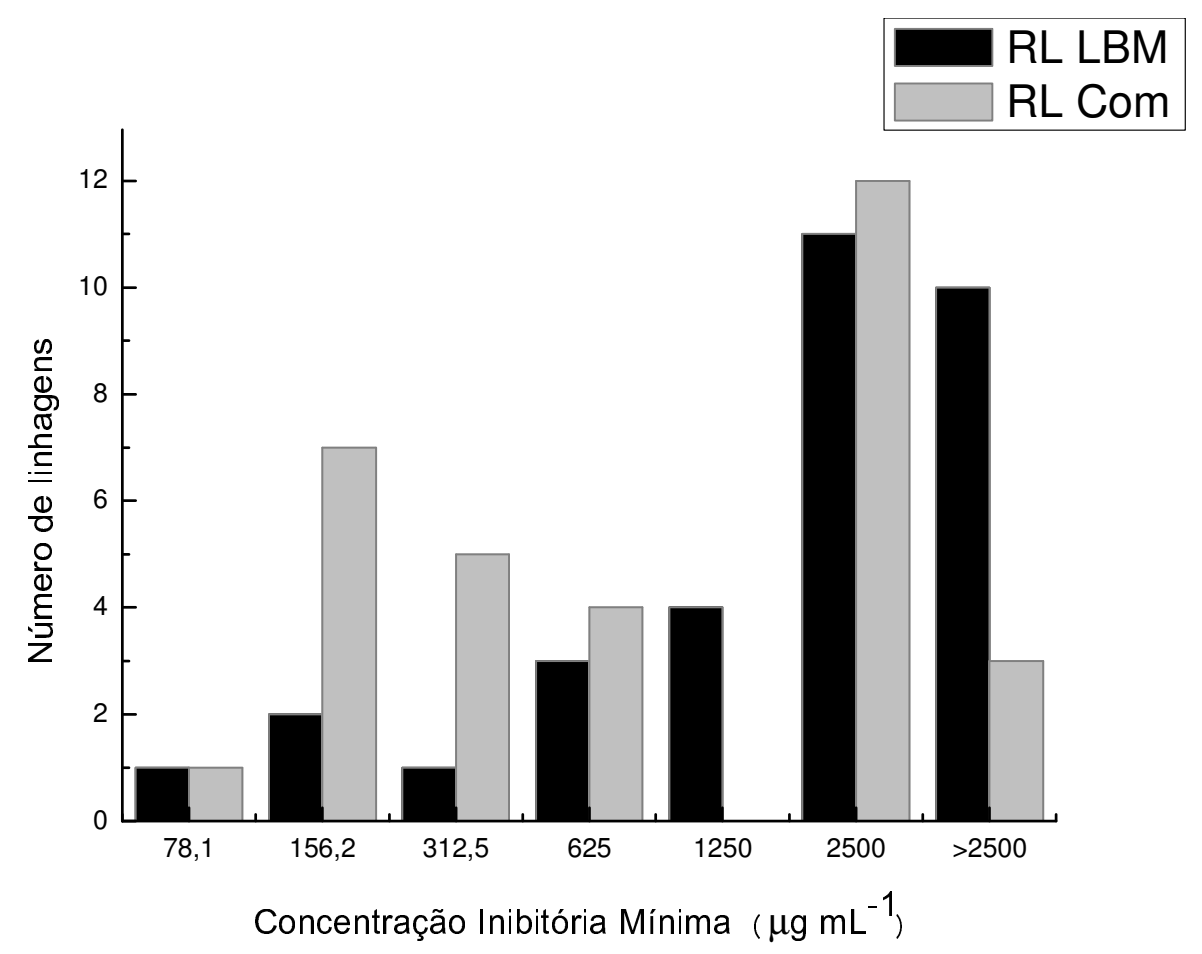

Figura 9 - Perfil de sensibilidade de L. monocytogenes a RL-LBM e RL-Com

Weimer (2008) relatou CIM de $6 \mu \mathrm{g} \mathrm{mL}^{-1}$ para o ramnolipídeo (JBR-425, Jeneil Biotech, Inc.) frente a $L$. monocytogenes 43251 , entretanto não existem outros trabalhos na literatura para fins comparativos.

Alguns autores avaliaram a atividade antimicrobiana de carboidratos ligados a ácidos graxos (carbohydrate fatty acid - CFA) (DEVULAPALLE et al., 2004; FERRER et al., 2005), estes compostos apresentam estrutura semelhante ao ramnolipídeo, pois possuem moléculas de açúcares ligadas a uma cadeia de ácido graxo e 
apresentam atividade emulsionante. Nobmann et al. (2009) avaliaram a atividade do CFA Metil 6-O-octanoil-a-D-glucopiranosídeo (Figura 10) sobre L. monocytogenes ATCC 7644 e relataram CIM de $800 \mu \mathrm{g} \mathrm{mL}$. Este resultado foi semelhante ao obtido neste trabalho com a mesma linhagem onde foi obtida a CIM de $1250 \mu \mathrm{g} \mathrm{m}^{-1}$ para o RL-LBM e $625 \mu \mathrm{g} \mathrm{mL}{ }^{-1}$ para o RL-Com (Tabela 7).

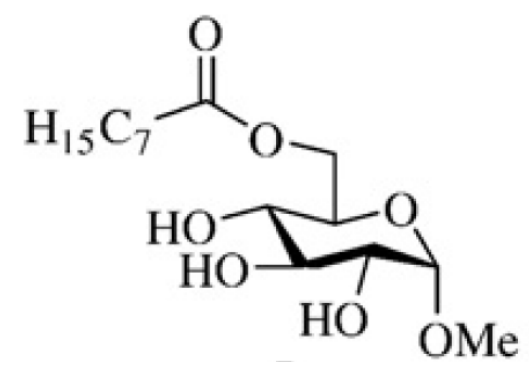

Figura 10 - Estrutura molecular do composto metil 6-O-octanoil-a-D-glucopiranosídeo (NOBMANN et al., 2009).

Alguns trabalhos relatam ainda a atividade antimicrobiana de ramnolipídeos sobre linhagens de outros importantes patógenos alimentares como Escherichia coli com CIM entre 64 - $250 \mu \mathrm{g} \mathrm{mL}^{-1}$ e Salmonella Thyphimurium com CIM entre 16 - 128 $\mu \mathrm{gL}^{-1}$ (BENINCASA et al., 2004; HABA et al., 2003).

Acredita-se que atividade antimicrobiana do $R L$ apresente como alvo a membrana citoplasmática já que sua característica anfipática permite a interação deste com a bicamada lipídica (HABA et al., 2003). Portanto, a composição lipídica da membrana plasmática deve representar um fator importante para a atividade antimicrobiana do RL. Verheul et al. (1997) compararam a composição lipídica da membrana plasmática de linhagens de L. monocytogenes Scott $A$ sensíveis e resistentes a nisina. Este estudo comprovou que havia nas células resistentes uma composição fosfolipídica diferente das células sensíveis.

Uma hipótese para as variações na sensibilidade frente ao $R L$ observadas para as 32 culturas avaliadas neste trabalho seria possíveis diferenças na composição lipídica da membrana das L. monocytogenes. 


\subsection{Efeito do RL sobre a permeabilidade celular de L. monocytogenes}

Para avaliar o efeito do RL na permeabilidade celular de L. monocytogenes foi realizado um teste para determinar o fator de absorção de iodeto de propídio das células tratadas com RL. Foram utilizados isolados com diferentes sensibilidades ao $\mathrm{RL}$ visando verificar se o grau de permeabilidade celular estava relacionado à inibição do crescimento bacteriano. Os isolados utilizados foram: L06 resistente ao $\mathrm{RL}(\mathrm{CIM}>2500)$ e isolado L12 sensível (CIM 156,2 $\mu \mathrm{g} \mathrm{mL-1}$ ) conforme mostrado na Tabela 9.

Tabela 9 - CIM dos ramnolipídeos sobre os isolados L06 e L12

\begin{tabular}{ccc}
\hline \multirow{2}{*}{ L. monocytogenes } & \multicolumn{2}{c}{ CIM } \\
\cline { 2 - 3 } & $\mathbf{R L}-L B M\left(\mu \mathrm{mL}^{-1}\right)$ & $\mathbf{R L}-C o m\left(\mu \mathrm{mL}^{-1}\right)$ \\
\hline L06 & $>2500$ & $>2500$ \\
L12 & 156,2 & 156,2 \\
\hline
\end{tabular}

Observando a Figura 11 nota-se que o aumento da concentração dos RLs resultou em um aumento no fator de absorção de iodeto de propídio, sugerindo que a presença do RL provocou alterações na permeabilidade da membrana celular para ambos os isolados. Observa-se ainda que o efeito foi mais pronunciado para o RLCom do que para o RL-LBM.

A maior permeabilidade celular na presença do RL-Com pode ser o motivo pelo qual este antimicrobiano foi mais eficiente que o RL-LBM na inibição do crescimento de L. monocytogenes. Esta diferença pode estar relacionada à presença de impurezas no RL-LBM e a composição de homólogos de cada $R L$, pois o RL-LBM apresenta maior concentração de di-ramnolipídeo e o RL-Com maior concentração de mono-ramnolipídeo.

Ao contrário do esperado, não houve diferença significativa entre o grau de permeabilidade dos dois isolados, sensível e resistente, frente aos dois RLs; além disso, o fator de permeabilidade não parece estar relacionado diretamente ao valor de CIM uma vez que, mesmo o isolado resistente apresentou aumento da permeabilidade na presença do RL. Este resultado sugere que, embora os RLs sejam capazes de modificar a permeabilidade celular, a atividade antimicrobiana deve estar relacionada a outros fatores característicos de cada bactéria tais como a 
composição da parede celular, composição de lipídeos de membrana ou outros mecanismos que podem trazer maior resistência à ação do antimicrobiano ou ainda (SANCHEZ et al., 2010; SOTIROVA et al., 2008). Os resultados indicam ainda que o mecanismo antimicrobiano dos ramnolipídeos pode apresentar outros sítios de ação além da membrana plasmática.

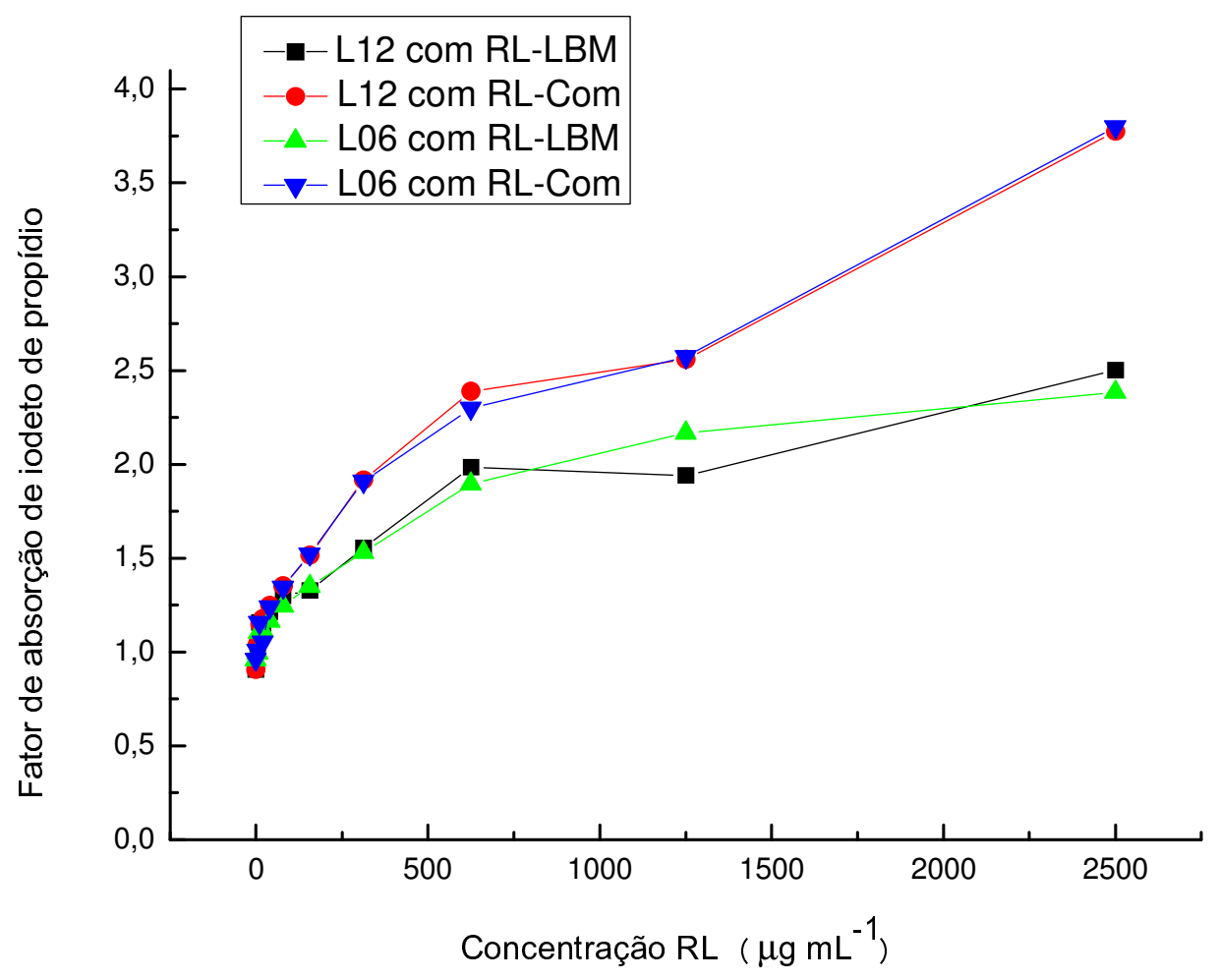

Figura 11 - Efeito de concentrações crescentes de $R L$ sobre a permeabilidade da membrana de $L$. monocytogenes L12 e L06

O aumento da permeabilidade celular causada pela ação do $R L$ é relatado em outros trabalhos. Ortiz et al. (2006) e Sanchez et al. (2006) avaliaram a ação do diramnolipídio em lipossomos de fosfolipídeos e concluíram que o $\mathrm{RL}$ interage com a bicamada lipídica provocando um desordenamento e um afastamento das bicamadas, o que aumenta a permeabilidade celular. Estas perturbações físicas à membrana podem afetar suas funções tal como a propriedade de barreira causando danos a célula.

Weimer (2008) também relatou um aumento na permeabilidade celular de $L$. monocytogenes pela ação do $R \mathrm{~L}$ relacionando este efeito a atividade antimicrobiana do biossurfatante. 
Sotirova et al. (2008) avaliaram a ação de RL sobre Bacillus subtilis constatando que os RLs aumentavam a permeabilidade celular deste microrganismo. Os autores sugeriram que o biossurfatante se acumula sobre a superfície da célula gerando "agregados" que permitem a formação de poros transmembrana, que funcionariam como canais que diminuem a barreira celular.

Os resultados obtidos neste trabalho confirmam observações anteriores de que os ramnolipídeos aumentam a permeabilidade celular bacteriana, contudo seu mecanismo de ação antimicrobiana ainda precisa ser elucidado.

\subsection{Interação Ramnolipídeo e Nisina}

A interação entre antimicrobianos é sinérgica quando o uso de dois antimicrobianos de forma combinada produz um efeito inibitório melhor que o uso isolado dos mesmos (ESTEBAN; PALOP, 2011). Gandhi et al. (2007) relataram que o uso do ramnolipídeo potencializa a ação da nisina, contudo o efeito desta interação não foi determinado.

Para verificar o tipo de interação entre $R L$ e nisina avaliou-se a ação conjunta destes antimicrobianos sobre L. monocytogenes utilizando o teste checkerboard. Foram utilizados dois isolados com sensibilidades diferentes ao RL, o L17 menos sensível, com CIM de $2500 \mu \mathrm{g} \mathrm{mL}^{-1}$, e o L12 mais sensível, com CIM de 156,2 $\mu \mathrm{g}$ $\mathrm{mL}^{-1}$.

Antes de elaborar o painel checkerboard com as combinações de RL-Com e nisina foi determinada a atividade antimicrobiana individual de cada agente sobre os isolados testados como mostra a Tabela 10.

Tabela 10 - Valores de CIM do RL-Com e da Nisina sobre os isolados L12 e L17

\begin{tabular}{ccc}
\hline & \multicolumn{3}{c}{ CIM } \\
\cline { 2 - 3 } L. monocytogenes & $\mathrm{RL}-\mathrm{Com}\left(\mu \mathrm{g} \mathrm{\textrm {mL } ^ { - 1 }}\right)$ & Nisina $\left(\mathrm{UI} \mathrm{\textrm {mL } ^ { - 1 } )}\right.$ \\
\hline L12 & 156,2 & 620 \\
L17 & 2500 & 640 \\
\hline
\end{tabular}

A nisina é um preservante muito utilizado em alimentos no controle de $L$. monocytogenes. Há relatos na literatura de valores de CIM de nisina sobre linhagens 


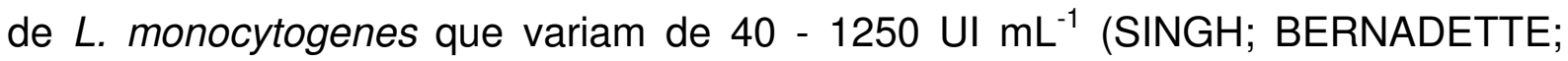
ADAMS, 2001; SZABO; CAHILL, 1998).

O mecanismo de ação antimicrobiana da nisina ainda não foi completamente elucidado. Propõe-se que a nisina pode modificar a permeabilidade da membrana de duas formas. O primeiro mecanismo ocorre pela ligação da nisina com lipídeos aniônicos da membrana, esta ligação se dá através de interações eletrostáticas entre a nisina, que possui carga positiva, e o lipídeo com carga negativa. Há um acumulo dos peptídeos na superfície da membrana que levam a formação de estruturas semelhantes a poros (TONG et al., 2010). O segundo mecanismo de ação ocorre pela ligação específica entre a nisina e o lipídeo II da membrana. O lipídeo II é um componente de membrana que atua na síntese da parede celular, este lipídeo é responsável por carrear subunidades de peptideoglicano do citosol para a parede celular. A nisina se liga ao lipídeo II pelos anéis do lado $\mathrm{N}$ terminal do peptídeo, esta ligação permite que a nisina insira a parte hidrofóbica da molécula dentro da membrana (Figura 12 b-c). Outros complexos nisina-lipídio II são formados, estes se unem a outras moléculas de nisina livre formando um poro transmembrana (Figura $12 \mathrm{~d}$ ). Os poros formados causam colapso na força próton motiva levando à morte celular (BREUKINK; DE KRUIJFF, 2006; CLEVELAND et al., 2001).

De acordo com o mecanismo de ação proposto, ambos ramnolipídeo e nisina, promovem alterações sobre a permeabilidade celular e, portanto, partiu-se da hipótese que a ação combinada das duas moléculas poderia gerar um efeito sinérgico. 


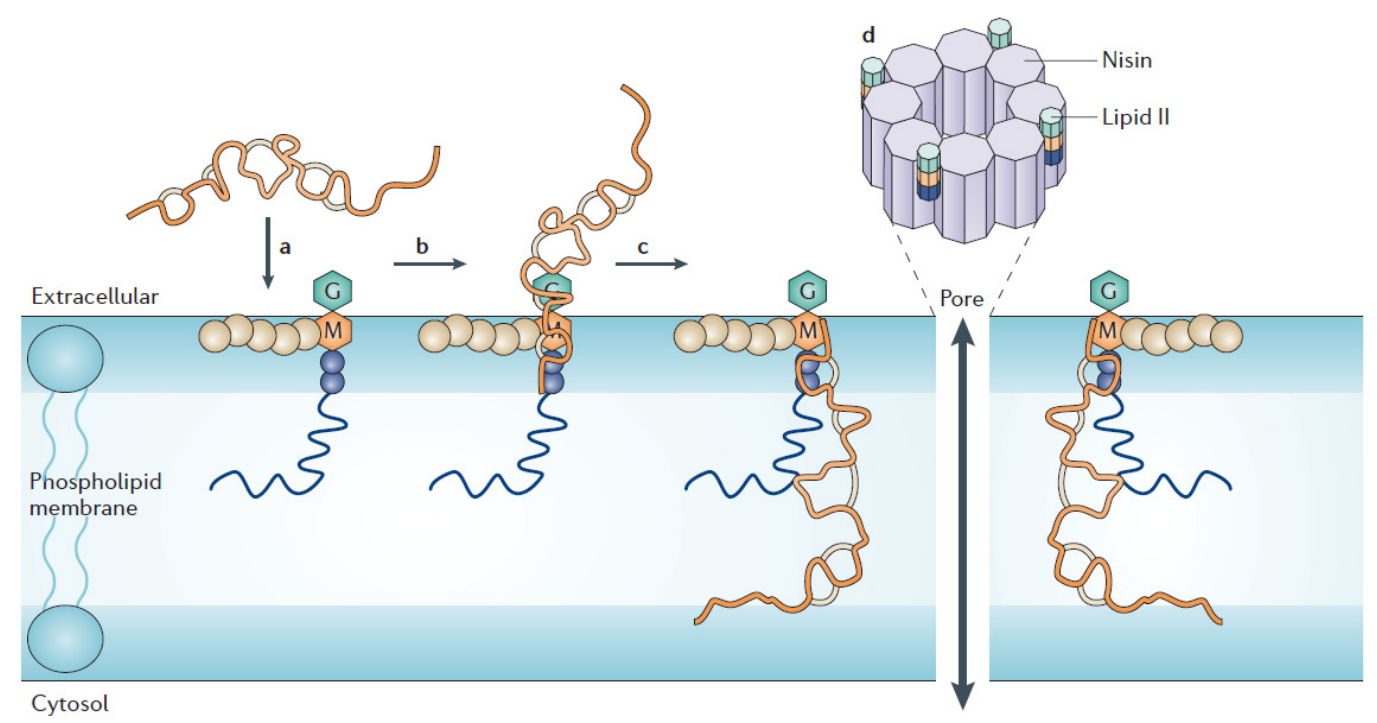

Figura 12 - Modo de ação da nisina para a formação de poros na membrana plasmática. a) A nisina se aproxima da membrana plasmática, b) liga-se ao Lipídio II da membrana pelo domínio $\mathrm{N}$ terminal da nisina, c) orienta-se de forma que a parte hidrofóbica da nisina fique dentro da membrana. d) Outros complexos Nisina-Lipídio II interagem com outras moléculas de nisina formando um poro transmembrana (BREUKINK; DE KRUIJFF, 2006)

A Figura 13 a) e b) representa esquematicamente o resultado obtido na placa de microtitulação durante o teste de checkerboard. As casas em cinza representam as combinações em que houve crescimento microbiano e as brancas onde não houve crescimento. A partir da combinação com a CIM individual dos antimicrobianos, foi determinado o índice CIF. 
a)

A

\begin{tabular}{|c|c|c|c|c|c|c|c|c|c|}
\hline & $\begin{array}{c}1 / 32 \\
\mathrm{CIM} \\
\mathrm{RL}\end{array}$ & $\begin{array}{c}1 / 16 \\
\text { CIM } \\
\text { RL }\end{array}$ & $\begin{array}{l}1 / 8 \\
\text { CIM } \\
\text { RL }\end{array}$ & $\begin{array}{c}1 / 4 \\
\text { CIM } \\
\text { RL }\end{array}$ & $\begin{array}{l}1 / 2 \\
\text { CIM } \\
\text { RL }\end{array}$ & $\begin{array}{l}\text { CIM } \\
\text { RL }\end{array}$ & $\begin{array}{c}2 \\
\text { CIM } \\
\text { RL }\end{array}$ & \multirow{8}{*}{ 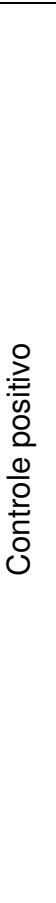 } & \\
\hline $\begin{array}{l}1 / 32 \\
\mathrm{CIM} \\
\mathrm{Nis} \\
\end{array}$ & & & & & & & & & \\
\hline $\begin{array}{l}1 / 16 \\
\mathrm{CIM} \\
\text { Nis } \\
\end{array}$ & & & & & & & & & \\
\hline $\begin{array}{l}1 / 8 \\
\mathrm{CIM} \\
\mathrm{Nis} \\
\end{array}$ & & & & & & & & & 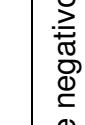 \\
\hline $\begin{array}{l}1 / 4 \\
\mathrm{CIM} \\
\mathrm{Nis}\end{array}$ & & & & & & & & & ర్ \\
\hline $\begin{array}{l}1 / 2 \\
\text { CIM } \\
\text { Nis }\end{array}$ & & & & & & & & & \\
\hline $\begin{array}{l}\text { CIM } \\
\text { Nis }\end{array}$ & & & & & & & & & \\
\hline $\begin{array}{c}2 \\
\mathrm{CIM} \\
\mathrm{Nis}\end{array}$ & & & & & & & & & \\
\hline
\end{tabular}

b)

$\begin{array}{llllllllllll}1 & 2 & 3 & 4 & 5 & 6 & 7 & 8 & 9 & 10 & 11 & 12\end{array}$

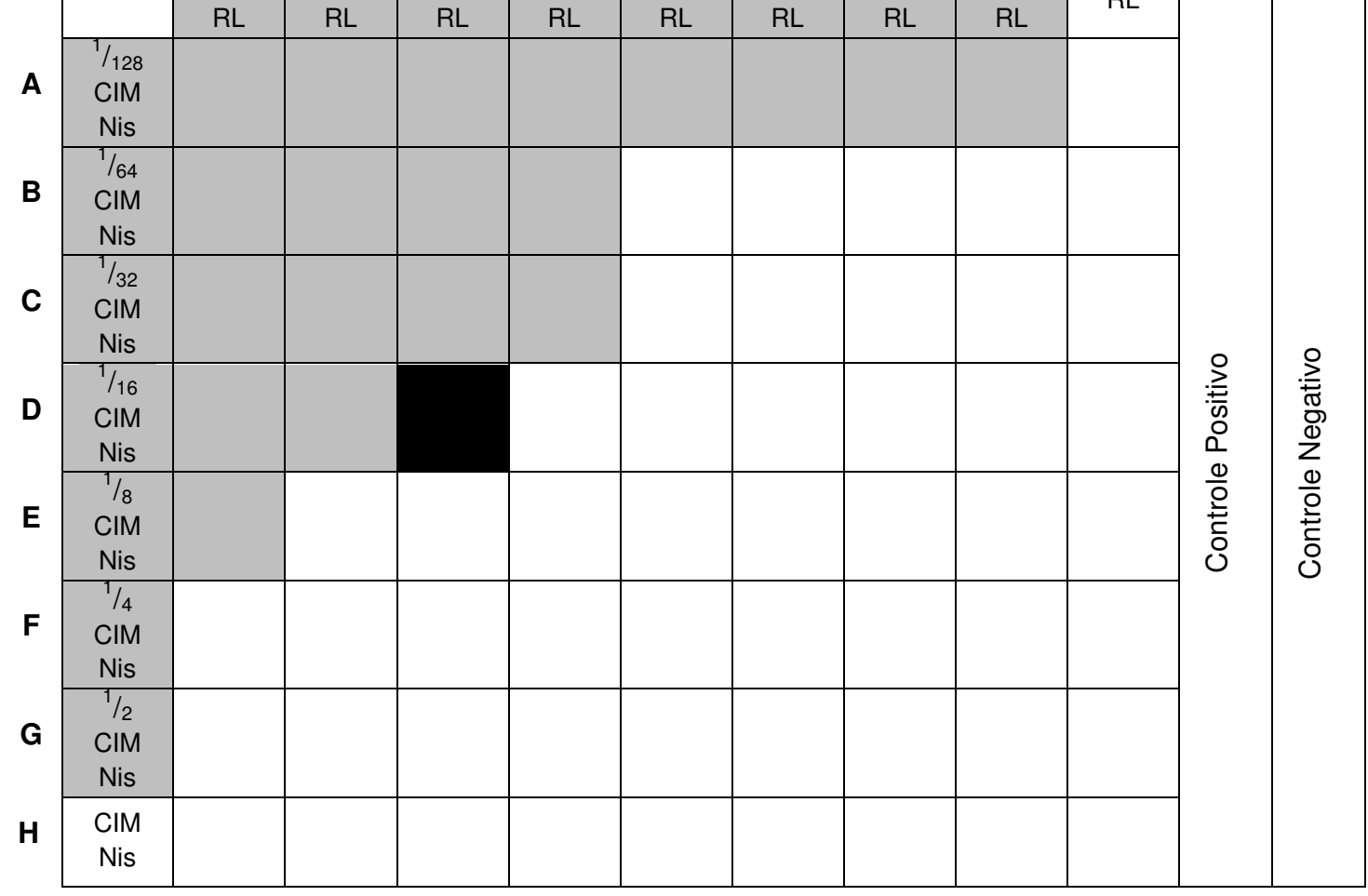

Figura 13 - Representação da microplaca para o teste checkerboard para os isolados L12 (a) e L17 (b) utilizando a combinação do $R L$ com nisina. Em cinza as cavidades em que houve crescimento microbiano e em branco onde não houve crescimento. Destacado em preto o valor de concentrações que foram utilizados para o cálculo do ICIF 
Os resultados da combinação dos antimicrobianos $\mathrm{RL}$ - Com e nisina frente ao isolado L12 (CIM 156,2 $\mathrm{g} \mathrm{mL}^{-1} \mathrm{RL}$ e $320 \mathrm{UI} \mathrm{mL}^{-1}$ nisina) e isolado L17 (CIM 2500 $\mu \mathrm{g} \mathrm{mL}^{-1} \mathrm{RL}$ e $640 \mathrm{UI} \mathrm{mL}^{-1}$ nisina) são mostrados na Tabela 11. Em ambos os casos o índice CIF da interação dos antimicrobianos, calculado utilizando a eq 2, foi $<0,5$ o que confirma a hipótese do efeito sinérgico sobre L. monocytogenes .

Tabela 11 - Valores de CIM dos antimicrobianos RL comercial e nisina individualmente e em combinação e índice CIF da interação dos antimicrobianos

\begin{tabular}{ccccccccc}
\hline & \multicolumn{9}{c}{ RL-Com $\left(\mu \mathrm{mL}^{-1}\right)$} & \multicolumn{3}{c}{ Nisina $\left(\mathrm{IU} \mathbf{~ m L}^{-1}\right)$} & & \\
\cline { 2 - 6 } L. monocytogenes & $\mathrm{CIM}$ & $\mathrm{CIM}_{\mathrm{c}}$ & $\mathrm{CIF}$ & $\mathrm{CIM}$ & $\mathrm{CIM}_{\mathrm{c}}$ & $\mathrm{CIF}$ & \multirow{2}{*}{ ICIF } & Interação \\
\hline L12 & 156,2 & 19,1 & 0,12 & 320 & 20 & 0,062 & 0,18 & Sinérgica \\
L17 & 2500 & 39,1 & 0,016 & 640 & 40 & 0,062 & 0,078 & Sinérgica
\end{tabular}

$\mathrm{CIM}_{\mathrm{c}}$ Concentração inibitória mínima na combinação

Para o isolado L12 a concentração inibitória mínima na combinação foi de 1/8 CIM do RL e 1/16 CIM da nisina e para o isolado L17 foi de 1/64 CIM do RL e 1/16 CIM da nisina. Este resultado demonstra que a concentração de ambos os antimicrobianos foi reduzida quando utilizados em conjunto proporcionando o uso de menor concentração para um mesmo efeito inibitório. Nota-se ainda que o sinergismo foi mais pronunciado no caso do isolado mais resistente (L17) que apresentou um ICIF menor que do isolado L12.

Alguns trabalhos avaliaram o efeito sinérgico da interação da nisina com outros antimicrobianos. Murdock et al. (2007) avaliaram a interação entre lactoferrina, uma glicoproteína presente no leite, e nisina sobre Listeria monocytogenes Scott A obtendo um ICIF de 0,35. Esteban e Palop (2011) analisaram a interação com carvocrol e Razavi Rohani et al. (2011) com óleo essencial de alho, ambos relatando efeito sinérgico.

O mecanismo da interação $R L$ e nisina ainda não foi elucidado. Alguns trabalhos envolvendo compostos com características semelhantes ao $R L$ já foram descritos.

A sacarose - ácido graxo é um surfatante que assim como RL possui uma molécula de açúcar ligada a uma cadeia de ácido graxo, apresentando característica anfipática e propriedades tensoativas. O uso combinado da nisina e da sacarose- 
ácido graxo demonstrou efeito sinérgico sobre L. monocytogenes, sendo que a CIM da nisina passou de $100 \mathrm{UI} \mathrm{mL} \mathrm{m}^{-1}$ para $25 \mathrm{UI} \mathrm{mL}^{-1}$ quando utilizada em conjunto com 0,01\% (p/v) de sacarose-ácido graxo (THOMAS et al. 1998).

A composição lipídica da membrana da célula alvo é um importante fator para a atividade antimicrobiana da nisina. A presença de um número maior de lipídeos de membrana carregados negativamente favorece a ligação da nisina à célula alvo tornando-a mais sensível a ação do antimicrobiano (CLEVELAND et al., 2001). Li et al. (2002) verificaram que o condicionamento das células de L. monocytogenes com o surfatante Tween 20 levou a uma alteração na composição lipídica da membrana com um aumento na concentração de lipídeos aniônicos. Este condicionamento tornou as células mais sensíveis a ação da nisina, pois o aumento na carga negativa na superfície da membrana favorece a ligação da nisina potencializando assim sua atividade antimicrobiana.

A presença do grupo carboxilato nos ramnolipídeos confere um caráter aniônico ao biossurfatante (Figura 1) (NGUYEN et al., 2008). Quando o RL interage com a membrana celular o grupo carboxilato com carga negativa tende a ordenarse na superfície da bicamada lipídica em contato com o meio aquoso. Este fato poderia levar a um aumento na carga negativa da superfície celular favorecendo a ligação da nisina que possui carga positiva, promovendo o efeito sinérgico observado.

A permeabilização da membrana gerada pela ação do $R L$ também pode aumentar a suscetibilidade da célula à ação da nisina já que este antimicrobiano tem como alvo a membrana celular. Logo na presença de $\mathrm{RL}$ o efeito da nisina é potencializado permitindo assim 0 uso de menores concentrações deste antimicrobiano.

\subsection{Curva de sobrevivência}

Para evidenciar o efeito do tempo sobre a atividade antimicrobiana foram construídas curvas de sobrevivência com os isolados $L$. monocytogenes L12 e L17 utilizando os antimicrobianos RL- Com e nisina, separadamente e em combinação.

As curvas com o RL-Com e nisina foram determinadas utilizando-se a CIM individual de cada antimicrobiano (Tabela 11). Para as curvas com interação foi utilizada a combinação com menor concentração encontrada no teste checkerboard 
em que foi observada atividade bactericida. As concentrações bactericidas dos antimicrobianos em combinação para $\mathrm{L} 12$ foram de $78,1 \mu \mathrm{g} \mathrm{mL} \mathrm{m}^{-1}$ de $\mathrm{RL}$ e $160 \mathrm{UI}$ $\mathrm{mL}^{-1}$ de nisina e para a $\mathrm{L} 17$ foram de $156,2 \mu \mathrm{g} \mathrm{mL}^{-1}$ de $\mathrm{RL}$ e $320 \mathrm{UI} \mathrm{mL}^{-1}$ de nisina (Tabela 12).

Tabela 12 - Concentração bactericida mínima do $R L$ e da nisina individualmente e em combinação

\begin{tabular}{ccccc}
\hline \multirow{2}{*}{ L. monocytogenes } & \multicolumn{2}{c}{$\mathrm{RL}\left(\mu \mathrm{gL}^{-1}\right)$} & \multicolumn{2}{c}{ Nisina $\left(\mathrm{Ul} \mathrm{mL}^{-1}\right)$} \\
\cline { 2 - 5 } & $\mathrm{CBM}$ & $\mathrm{CBM}_{\mathrm{c}}$ & $\mathrm{CBM}$ & $\mathrm{CBM}_{\mathrm{c}}$ \\
\hline L12 & 156,2 & 78,1 & 320 & 160 \\
L17 & $>2500$ & 156,2 & 640 & 320 \\
\hline
\end{tabular}

$\mathrm{CBM}_{\mathrm{c}}$ - concentração bactericida mínima na combinação

A curva de sobrevivência para o isolado L12 (Figura 14) demonstra que o RL

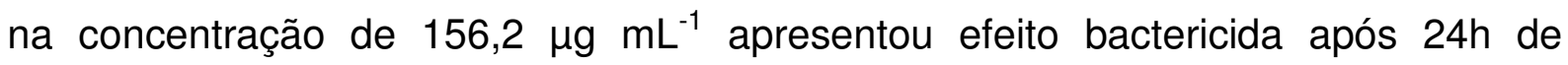

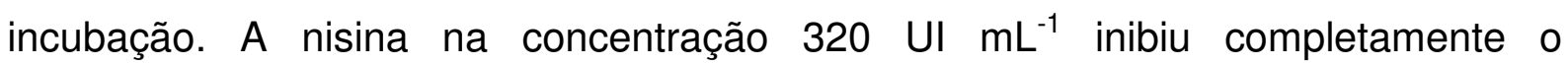
crescimento já nos primeiros 30 min de incubação. A combinação de $R L$ e nisina contendo 1/2 da CIM do RL e 1/2 da CIM da nisina mostrou-se bactericida a partir de $30 \mathrm{~min}$.

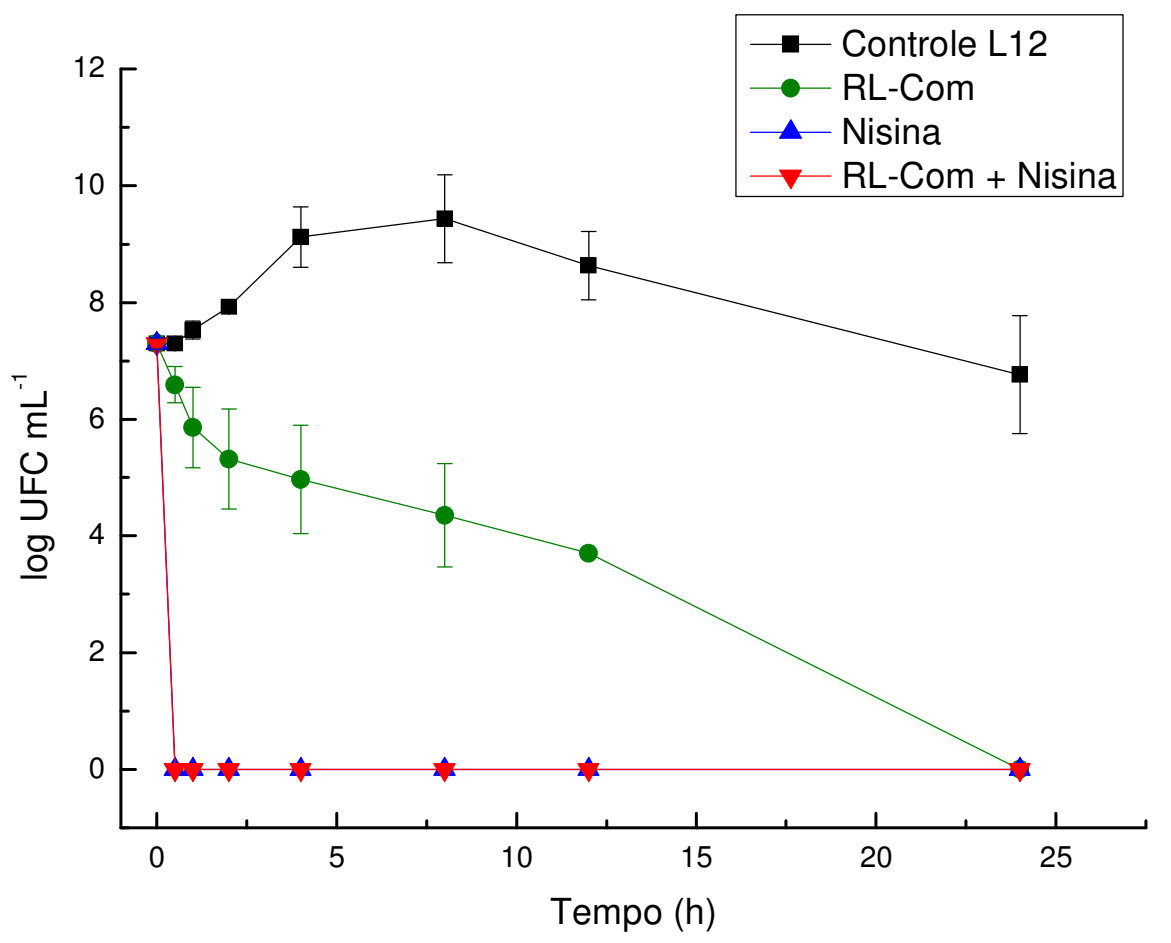

Figura 14 - Curva de sobrevivência de L. monocytogenes L12 para o tratamento com $R L(156,2 \mu \mathrm{g}$ $\left.\mathrm{mL}^{-1}\right)$, nisina (320 UI mL $\left.{ }^{-1}\right)$, combinação de $\mathrm{RL}\left(78,1 \mu \mathrm{g} \mathrm{mL}^{-1}\right)+$ nisina $\left(160 \mathrm{UI} \mathrm{mL} \mathrm{L}^{-1}\right)$ e o controle. 
Observa-se que o tempo de resposta da nisina individualmente foi o mesmo determinado para a combinação, contudo as concentrações utilizadas foram menores demonstrando o potencial da interação.

Para o isolado L17 (Figura 15) o RL na concentração de $2500 \mu \mathrm{g} \mathrm{mL}^{-1}$ não apresentou atividade bactericida, mas sim bacteriostática, pois observa-se que não houve redução significativa no número de células viáveis. A nisina (640 Ul $\mathrm{mL}^{-1}$ ) apresentou efeito bactericida a partir de $4 \mathrm{~h}$ de tratamento e a combinação de 156,2

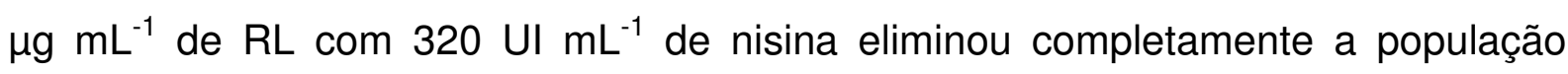
bacteriana a partir de $2 \mathrm{~h}$ de tratamento. A Figura 16 ilustra o aspecto visual dos tubos de ensaio onde foi realizado o experimento.

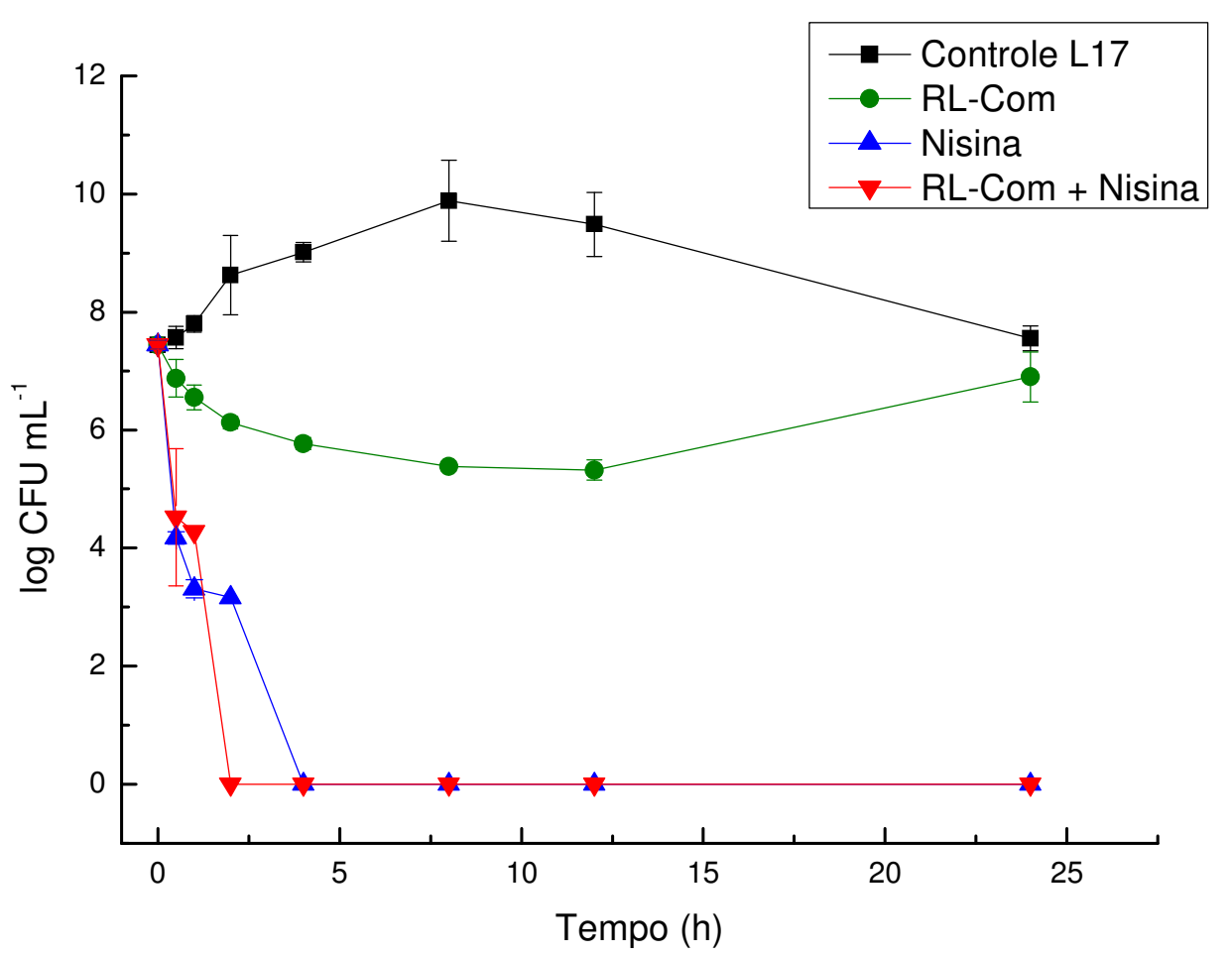

Figura 15 - Curva de sobrevivência de L. monocytogenes $\mathrm{L} 17$ para o tratamento com $\mathrm{RL}(2500 \mu \mathrm{g}$ $\left.\mathrm{mL}^{-1}\right)$, nisina $\left(640 \mathrm{UI} \mathrm{mL}^{-1}\right)$, combinação de $\mathrm{RL}\left(156,2 \mu \mathrm{gLL}^{-1}\right)+$ nisina $\left(320 \mathrm{UI} \mathrm{mL}^{-1}\right)$ e o controle.

Para o teste com o uso combinado dos antimicrobianos frente ao isolado $L 17$ houve uma redução não apenas na concentração dos antimicrobianos, mas também no tempo de resposta aos agentes. $O$ isolado $L 17$ é mais resistente ao $R L$ que a $L 12$ e o uso combinado de $R L$ e nisina propiciou uma redução significativa na 
concentração de $\mathrm{RL}$ de $2500 \mu \mathrm{g} \mathrm{mL}^{-1}$ para $156,2 \mu \mathrm{g} \mathrm{mL} \mathrm{m}^{-1}$ além de obter resultado bactericida não obtido com o uso isolado de $R L$.

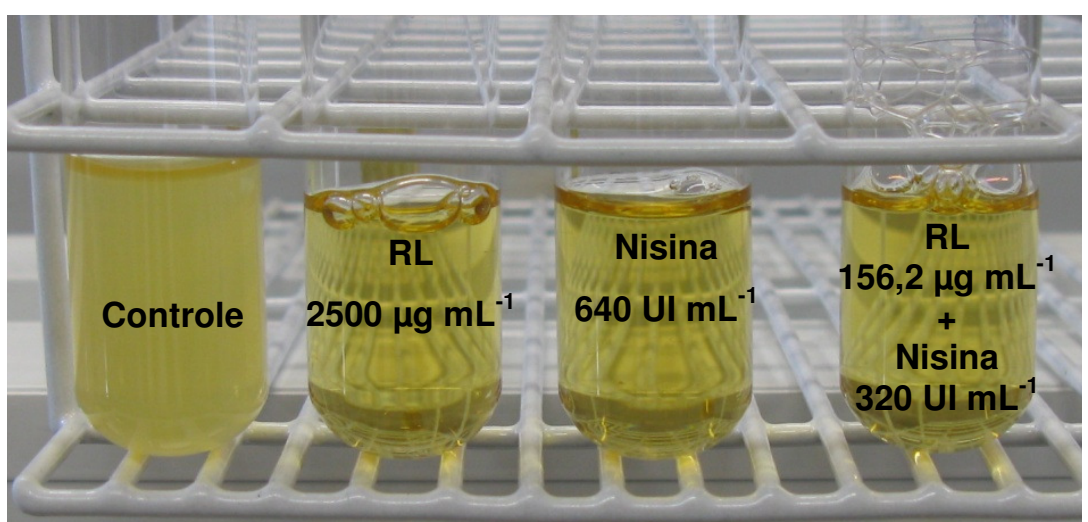

Figura 16 - llustração do ensaio para a curva de sobrevivência de L. monocytogenes L17 e os tratamentos com $\mathrm{RL}\left(2500 \mu \mathrm{g} \mathrm{mL}^{-1}\right)$, nisina $\left(640 \mathrm{UI} \mathrm{mL}^{-1}\right)$ e a combinação $\mathrm{RL}\left(156,2 \mu \mathrm{g} \mathrm{mL}^{-1}\right)+$ nisina (320 $\mathrm{UI} \mathrm{mL}^{-1}$ ) após $24 \mathrm{~h}$ de tratamento

A curva de sobrevivência possibilitou evidenciar o perfil de ação dos antimicrobianos, isolados e em combinação, durante o crescimento populacional. $O$ ramnolipídeo mostrou-se efetivo sugerindo o seu possível uso como agente no controle de L. monocytogenes.

\subsection{Principais Resultados}

- O Ramnolipídeo LBM purificado apresentou como componente principal o diramnolipídeo (43,7\%), enquanto que para o ramnolipídeo comercial o monoramnolipídeo foi o componente majoritário (37,67\%);

- Ambos os RLs apresentaram atividade antimicrobiana sobre L. monocytogenes, com CIM que variaram entre 78,1 a $2500 \mu \mathrm{g} \mathrm{mL}^{-1}$,

- A ação dos RLs foi predominantemente bacteriostática;

- $68,7 \%$ das L. monocytogenes testadas foram sensíveis ao RL-LBM e 90,6\% foram sensíveis ao RL-Com;

- O RL-LBM e o RL-Com aumentaram a permeabilidade celular de $L$. monocytogenes L06 e L12, mas este efeito não mostrou-se estar diretamente relacionado a atividade antimicrobiana observada; 
- A nisina apresentou CIM de $320 \mathrm{UI} \mathrm{mL}^{-1}$ para o isolado $\mathrm{L} 12$ e de $640 \mathrm{UI} \mathrm{mL}^{-1}$ para o isolado L17;

- A interação entre a nisina e o RL foi sinérgica. O ICIF para o isolado L12 foi de 0,18 e para o L17 0,078;

- O RL na concentração de 156,2 $\mu \mathrm{g} \mathrm{mL}^{-1}$ apresentou efeito bactericida sobre $L$. monocytogenes L12 após $24 \mathrm{~h}$ de incubação. A nisina na concentração de $320 \mathrm{UI}$ $\mathrm{mL}^{-1}$ inibiu completamente $\mathrm{o}$ crescimento aos $30 \mathrm{~min}$ de incubação. A combinação de 1/2 da CIM do RL e 1/2 da CIM da nisina foi bactericida aos 30 min de incubação; - Para o isolado de L. monocytogenes L17, o RL na concentração de $2500 \mu \mathrm{g}$ $\mathrm{mL}^{-1}$ mostrou atividade bacteriostática. A nisina na concentração de $640 \mathrm{UI} \mathrm{mL}^{-1}$ apresentou efeito bactericida em $4 \mathrm{~h}$ de incubação e a combinação contendo 156,2

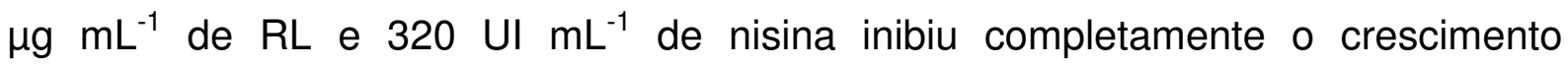
bacteriano em 2 h de tratamento.

\subsection{Considerações Finais}

Neste trabalho foi possível observar que o biossurfatante ramnolipídeo apresenta potencial antimicrobiano sobre L. monocytogenes. Trabalhos anteriores comprovam que o ramnolipídeo apresenta também atividade antiadesiva sobre $L$. monocytogenes e atividade antimicrobiana sobre outros patógenos de origem alimentar como Escherichia coli e Salmonella Thyphimurium.

O ramnolipídeo possui baixa toxicidade e alta biodegradabilidade o que, aliado as suas propriedades emulsionantes, permitiria seu uso na formulação de alimentos, podendo-se utilizar concentrações superiores as testadas neste trabalho.

Além disso, os RLs potencializam a atividade antimicrobiana da nisina sobre L. monocytogenes, pois a interação entre esses dois agentes mostrou-se sinérgica.

Este estudo comprova, portanto que o $R \mathrm{~L}$ possui potencial para diversas aplicações em alimentos, podendo ser utilizado como um preservante para 0 controle de $L$. monocytogenes de forma isolada ou em conjunto com a nisina. 


\section{CONCLUSÕES}

Os ramnolipídeos produzidos por Pseudomonas aeruginosa $\mathrm{LBI}$ e $\mathrm{O}$ ramnolipídeo comercial apresentam potencial antimicrobiano sobre $L$. monocytogenes. A ação antilisterial dos ramnolipídeos não possui um caráter bactericida, mas sim bacteriostático.

Foi comprovado que os ramnolipídeos aumentam a permeabilidade celular de $L$. monocytogenes, mas este efeito não esteve diretamente relacionado a ação antimicrobiana observada frente aos isolados testados.

Os ramnolipídeos potencializam a ação da nisina mostrando interação sinérgica com este antimicrobiano frente aos isolados de L. monocytogenes testados. 


\section{PERSPECTIVAS FUTURAS}

Para complementar o trabalho aqui realizado poderia ser avaliada a atividade antimicrobiana dos componentes majoritários, presentes nas misturas de homólogos de ramnolipídeo. Esta avaliação ajudaria compreender como cada homólogo contribui para o potencial antimicrobiano do produto.

O sinergismo entre nisina e RL poderia ser avaliado utilizando um número maior de linhagens de L. monocytogenes, além de verificar este efeito sobre outros microrganismos de interesse em alimentos (Bacillus cereus, Staphylococcus aureus, Salmonella enteritidis, Escherichia coli, Clostridium botulinum).

Avaliar a atividade antimicrobiana dos ramnolipídeos em diferentes condições de $\mathrm{pH}$ e temperatura, a fim verificar a influência dos fatores encontrados em alimentos no potencial antilisterial dos ramnolipídeos.

Para melhor compreender o mecanismo de ação dos ramnolipídeos poderia ser analisada a composição lipídica da membrana celular das diferentes linhagens de L. monocytogenes testadas relacionando-se com a sensibilidade observada. 


\section{REFERÊNCIAS}

ABALOS, A.; PINAZO, A.; INFANTE, M. R.; CASALS, M.; GARCIA, F.; MANRESA, A. Physicochemical and antimicrobial properties of new rhamnolipids produced by Pseudomonas aeruginosa AT10 from soybean oil refinery wastes. Langmuir, v. 17, n. 5, p. 1367-1371, 2001.

ABEE, T.; ROMBOUTS, F. M.; HUGENHOLTZ, J.; GUIHARD, G.; LETELLIER, L. Mode of action of nisin z against Listeria monocytogenes Scott A grown at high and low temperatures. Applied and Environmental Microbiology, v. 60, n. 6, p. 19621968, 1994.

ABDEL-MAWGOUD, A. M.; LÉPINE, F.; DÉZIEL, E. Rhamnolipids: diversity of structures, microbial origins and roles. Applied Microbiology and Biotechnology, v. 86, n. 5 , p. 1323-1336, 2010.

ADAK, G.; LONG, S.; O'BRIEN, S. Trends in indigenous food-borne disease and deaths, England and Wales: 1992 to 2000. Gut, v. 51, n. 6, p. 832-841, 2002.

ARAUJO, L. V. Ramnolipideo e surfactina: seus potenciais de uso na inibição da formação de biofilmes por Listeria monocytogenes em superfícies plásticas. 2009. 121f. Dissertação (Mestrado em Ciência de Alimentos) - Instituto de Química, Universidade Federal do Rio de Janeiro, Rio de Janeiro, 2009.

ARAUJO, L. V.; ABREU, F.; LINS, U.; ANNA, L. M. M. S.; NITSCHKE, M.; FREIRE, D. M. G. Rhamnolipid and surfactin inhibit Listeria monocytogenes adhesion. Food Research International, v. 44, p. 481-488, 2011.

BANAT, I. M.; FRANZETTI, A.; GANDOLFI, I.; BESTETTI, G.; MARTINOTTI, M. G.; FRACCHIA, L.; SMYTH, T. J.; MARCHANT, R. Microbial biosurfactants production, applications and future potential. Applied Microbiology and Biotechnology, v. 87, n. 2, p. 427-444, 2010.

BENINCASA, M.; ABALOS, A.; MOREIRA, I.; MANRESA, A. Rhamnolipid production by Pseudomonas aeruginosa LBI growing on soapstock as the sole carbon source. Journal of Food Engineering, v. 54, n. 4, p. 283-288, 2002.

BENINCASA, M.; ABALOS, A.; OLIVEIRA, I.; MANRESA, A. Chemical structure, surface properties and biological activities of the biosurfactant produced by Pseudomonas aeruginosa LBI from soapstock. Antonie Van Leeuwenhoek, v. 85, n. 1, p. 1-8, 2004. 
BENKERROUM, N.; SANDINE, W. E. Inhibitory action of nisin against Listeria monocytogenes. Journal of Dairy Science, v. 71, n. 12, p. 3237-3245, 1988.

BERENBAUM, M. C. What is synergy? Pharmacological Reviews; v. 41, n. 2, p. 93-141, 1989.

BREUKINK, E.; DE KRUIJFF, B. Lipid II as a target for antibiotics. Nature Reviews Drug Discovery, v. 5, n. 4, p. 321-32, 2006.

CARPENTIER, B.; CERF, O. Persistence of Listeria monocytogenes in food industry equipment and premises. Internetional Journal of Food Microbiology, v. 145, n. 1, p. 1-8, 2011.

CENTERS FOR DISEASE CONTROL AND PREVENTION (CDC). Disponível em: <http://www.cdc.gov/outbreaknet/investigations/> . Acesso em: 27 fev. 2012.

CENTERS FOR DISEASE CONTROL AND PREVENTION (CDC). Disponível em: $<$ http://www.cdc.gov/foodborneburden/PDFs/FACTSHEET_A_FINDINGS_updated413.pdf>. Acesso em: 8 dez. 2011a.

CENTERS FOR DISEASE CONTROL AND PREVENTION (CDC). Disponível em: $<$ http://www.cdc.gov/foodnet/annual/2000/2000final_report.pdf>. Acesso em: 9 ago. 2011b.

CLEVELAND, J.; MONTVILLE, T. J.; NES, I. F.; CHIKINDAS, M. L. Bacteriocins: safe, natural antimicrobials for food preservation. Internetional Journal of Food Microbiology, v. 71, n. 1, p. 1-20, 2001.

COTTER, P. D.; HILL, C.; ROSS, R. P. Bacteriocins: developing innate immunity for food. Nature Reviews Microbiology, v. 3, n. 10, p. 777-788, 2005.

CRUZ, C. D.; MARTINEZ, M. B.; DESTRO, M. T. Listeria monocytogenes: Um agente ainda pouco conhecido no Brasil. Alimentos e Nutrição, v. 19, n. 2, p. 195206, 2008.

DE MARTINIS, E. C. P.; ALVES, V. F.; FRANCO, B. D. G. M., Bioconservação de Alimentos. Biotecnologia Ciência \& Desenvolvimento, n. 29, p. 114-119, 2002. 
DENGLER, W. A.; SCHULTE, J.; BERGER, D. P.; MERTELSMANN, R.; FIEBIG, H. $H$. Development of a propidium iodide fluorescence assay for proliferation and cytotoxicity assays. Anticancer Drugs, v. 6, n. 4, p. 522-532, 1995.

DEVULAPALLE, K. S.; GÓMEZ DE SEGURA, A.; FERRER, M.; ALCALDE, M., MOOSER, G.; PLOU F. J. Effect of carbohydrate fatty acid esters on Streptococcus sobrinus and glucosyltransferase activity. Carbohydrate Research, v. 28, n. 6, p. 1029-1034, 2004.

DÉZIEL, E.; LEPINE, F.; DENNIE, D.; BOISMENU, D.; MAMER, O. A.; VILLEMUR, $R$. Liquid chromatography/mass spectrometry analysis of mixtures of rhamnolipids produced by Pseudomonas aeruginosa strain 57RP grown on mannitol or naphthalene. Biochimica et Biophysica Acta, v. 1440, n. 2-3, p. 244-252, 1999.

DUSANE, D. H.; NANCHARAIAH, V.; ZINJARDE, S. S.; VENUGOPALAN, V. P. Rhamnolipid mediated disruption of marine Bacillus pumilus biofilms. Colloids and Surfaces B:Biointerfaces, v. 81, n. 1, p. 1, p. 242-248, 2010.

DWORKIN, M.; FALKOW, S.; ROSENBERG, E.; SCHLEIFER, K.;

STACKEBRANDT, E. The prokaryotes. New York: Springer Science, 2006. v. 4.

EUROPEAN FOOD SAFETY AUTHORITY (EFSA). Request for updating the former SCVPH opinion on Listeria monocytogenes risk related to ready-to-eat foods and scientific advice on different levels of Listeria monocytogenes in ready-to-eat foods and the related risk for human illness. The EFSA Journal, v. 599, p. 1-42, 2007.

ELOFF, J. N. A sensitive and quick microplate method to determine the minimal inhibitory concentration of plant extracts for bacteria. Planta Medica, v. 64, n. 8, p. $711-713,1998$.

EPAND, R. M.; VOGEL, H. J. Diversity of antimicrobial peptides and their mechanisms of action. Biochimica et Biophysica Acta, v. 1462, n. 1-2, p. 1-28, 1999.

ESTEBAN, M. D.; PALOP, A. Nisin, carvacrol and their combinations against the growth of heat-treated Listeria monocytogenes cells. Food Technology and Biotechnology, v. 49, n. 1, p. 89-95, 2011.

FARBER, J. M.; PETERKIN, P. I. Listeria monocytogenes, a food-borne pathogen. Microbiological Reviews, v. 55, n. 3, p. 476-511, 1991. 
FERRER, M.; SOLIVERI, J.; PLOU, F. J.; LÓPEZ-CORTÉS, N.; REYES-DUARTE, D.; CHRISTENSEN, M.; COPA-PATIÑO, J. L.; BALLESTEROS, A. Synthesis of sugar esters in solvent mixtures by lipases from Thermomyces lanuginosus and Candida antarctica B, and their antimicrobial properties. Enzyme and Microbial Technology, v. 36, n. 4, p. 391-398, 2005

FOOD AND DRUG ADMINISTRATION (FDA). Listeria monocytogenes Risk Assessment: I. Introduction. Disponível em: <http://www.fda.gov/Food/ScienceResearch/ResearchAreas/RiskAssessmentSafety Assessment/ucm184052.htm>. Acesso em: 23 set. 2011 a.

FOOD AND DRUG ADMINISTRATION (FDA). Recall -- Firm Press Release.

Disponível em: <http://www.fda.gov/Safety/Recalls/ucm273141.htm> Acesso em: 26 out. $2011 b$.

GANDHI, M.; CHIKINDAS, M. L. Listeria: A foodborne pathogen that knows how to survive. International Journal of Food Microbiology, v. 113, n. 1, p. 1-15, 2007.

GANDHI, N. R.; SKEBBA, V. L. P. Rhamnolipid compositions and related methods of use. WO2007095258-A2, 23 aug. 2007.

GARCIA-GONZALEZ, L.; GEERAERD, A. H.; MAST, J.; BRIERS, Y.; ELST, K.; VAN GINNEKEN, L.; VAN IMPE, J.F.; DEVLIEGHERE, F. Membrane permeabilization and cellular death of Escherichia coli, Listeria monocytogenes and Saccharomyces cerevisiae as induced by high pressure carbon dioxide treatment. Food Microbiology, v. 27, n. 4, p. 541-549, 2010.

GUERRA, M. M.; BERNARDO, F. A. O risco da listeriose e a identificação do perigo - Revisão. Revista Portuguesa de Ciências Veterinárias, v. 99, n. 550, p. 69-76, 2004.

GUIOTTO, A.; POZZOBON, M.; CANEVARI, M.; MANGANELLI, R.; SCARIN, M.; VERONESE, F. M. PEGylation of the antimicrobial peptide nisin A: problems and perspectives. IL Farmaco, v. 58, n. 1, p. 45-50, 2003.

HABA, E.; PINAZO, A.; JAUREGUI, O.; ESPUNY, M. J.; INFANTE, M. R.; MANRESA. A. Physicochemical characterization and antimicrobial properties of rhamnolipids produced by Pseudomonas aeruginosa 47T2 NCBIM 40044.

Biotechnology and Bioengineering, v. 81, n. 3, p. 316-322, 2003. 
IRIE, Y.; O'TOOLE, G. A.; YUK, M. H. Pseudomonas aeruginosa rhamnolipids disperse Bordetella bronchiseptica biofilms. FEMS Microbiology Letters, v. 250, n. 2, p. 237-243, 2005.

JACK, R. W.; TAGG, J. R.; RAY, B. Bacteriocins of gram-positive bacteria.

Microbiological Reviews, v. 59, n. 2, p. 171-200, 1995.

LANG, S.; WULLBRANDT, D. Rhamnose lipids-biosynthesis, microbial production and application potential. Applied Microbiology and Biotechnology, v. 51, n. 1, p 22-32, 1999.

LI, J.; CHIKINDAS, M. L.; LUDESCHER, R. D.; MONTVILLE, T. J. Temperature- and surfactant-induced membrane modifications that alter Listeria monocytogenes nisin sensitivity by different mechanisms. Applied and Environmental Microbiology, v. 68, n. 12, p. 5904-5910, 2002.

LIU, D. Handbook of Listeria monocytogenes. Boca Raton: Taylor \& Francis , 2008, $540 \mathrm{p}$.

MACKAY, M. L.; MILNE, K.; GOULD, I. M. Comparison of methods for assessing synergic antibiotic interactions. International Journal of Antimicrobial Agents, v. 15, n. 2, p. 125-129, 2000.

MADIGAN, M. T.; MARTINKO, J. M.; DUNLAP, P. V.; CLARK, D. P. Microbiologia de Brock, Porto Alegre: Artimed, 2010. 1160 p.

MAIER, R. M.; SOBERÓN-CHÁVEZ, G. Pseudomonas aeruginosa rhamnolipids: biosynthesis and potential applications. Applied Microbiology and Biotechnology, v. 54, n 5, p. 625-633, 2000.

MANTILLA, S. P. S.; FRANCO, R. M.; OLIVEIRA, L. A. T.; SANTOS, E. B.; GOUVÊA, R. Importância da Listeria monocytogenes em alimentos de origem animal. Revista da FZVA, v. 14, n. 1, p. 180-192, 2007.

MARTÍNEZ, B.; RODRÍGUEZ, A. Antimicrobial susceptibility of nisin resistant Listeria monocytogenes of dairy origin. FEMS Microbiology Letters, v. 252, n. 1, p. 67-72, 2005.

McAULIFFE, O.; ROSS, R. P.; HILL, C. Lantibiotics: structure, biosynthesis and mode of action. FEMS Microbiology Reviews, v. 25, n. 3, p. 285-308, 2001. 
McLAUCHLIN, J. The relationship between Listeria and listeriosis. Food Control, v. 7, n. 4-5, p. 187-193, 1996.

MEAD, P. S.; SLUTSKER, L.; DIETZ, V.; Mc CAIG, L. F.; BRESEE, J. S.; SHAPIRO, C.; Food-related illness and death in the United States. Emerging Infectious Diseases, v. 5, n. 5, p. 607-625,1999.

MELETIADIS, J.; POURNARAS, S.; ROILIDES, E.; WALSH, T. J. Defining fractional inhibitory concentration index cutoffs for additive interactions based on self-drug additive combinations, Monte Carlo simulation analysis, and in vitro-in vivo correlation data for antifungal drug combinations against Aspergillus fumigates. Antimicrobial Agents and Chemotherapy, v. 54, n. 2, p. 602-609, 2010.

MELO, N. R.; SOARES, N. F. F.; GONÇALVES, M. J. Nisina: um conservante natural para alimentos. Revista Ceres, v. 52, n. 304, p. 921-938, 2005.

MØRETR $\varnothing$, T.; LANGSRUD, S. Listeria monocytogenes: biofilm formation and persistence in food-processing environments. Biofilms, v. 1, n. 2, p. 107-121, 2004.

MOSMANN, T. Rapid colorimetric assay for cellular growth and survival: application to proliferation and cytotoxicity assays. Journal of Immunological Methods, v. 65, n. 1-2, p. 55-63, 1983.

MURDOCK, C. A.; CLEVELAND, J.; MATTHEWS, K. R.; CHIKINDAS, M. L. The synergistic effect of nisin and lactoferrin on the inhibition of Listeria monocytogenes and Escherichia coli O157:H7. Letters in Applied Microbiology, v. 44, n. 3, p. 255261, 2007.

NGUYEN, T. T.; YOUSSEF, N. H.; MCINERNEY, M. J.; SABATINI, D. A. Rhamnolipid biosurfactant mixtures for environmental remediation. Water Research, v. 42, n. 6-7, p. 1735-1743, 2008.

NITSCHKE, M.; COSTA, S. G. V. A. O.; HADDAD, R.; GONÇALVES, L. A. G.; EBERLIN, M. N.; CONTIERO, J. Oil wastes as unconventional substrates for rhamnolipid biosurfactant production by Pseudomonas aeruginosa LBI.

Biotechnology Progress, v. 21, n. 5, p. 1562-1566, 2005.

NITSCHKE, M.; COSTA, S. G. V. A. O.; CONTIERO, J. Structure and applications of a rhamnolipid surfactant produced in soybean oil waste. Applied Biochemistry and Biotechnology, v. 160, n. 7, p. 2066-2074, 2010. 
NITSCHKE, M.; COSTA, S. G. V. A. O.; CONTIERO, J. Rhamnolipids and PHAs:

Recent reports on Pseudomonas-derived molecules of increasing industrial interest.

Process Biochemistry, v. 46, n. 3, p. 621-630, 2011.

NOBMANN, P.; SMITH, A.; DUNNE, J.; HENEHAN, G.; BOURKE, P. The antimicrobial efficacy and structure activity relationship of novel carbohydrate fatty acid derivatives against Listeria spp. and food spoilage microorganisms.

International Journal of Food Microbiology, v. 128, n. 3, p. 440-445, 2009.

NYACHUBA, D. G. Foodborne illness: is it on the rise? Nutrition Reviews, v. 68, n. 5, p. 257-269, 2010.

ORTIZ, A.; TERUEL, J. A.; ESPUNY, M. J.; MARQUÉS, A.; MANRESA, A., ARANDA, F. J. Effects of dirhamnolipid on the structural properties of phosphatidylcholine membranes. International Journal of Pharmaceutics, v. 325, n. 1-2, p. 99-107, 2006.

OSTROSKY, E. A.; MIZUMOTO, M. K.; LIMA, M. E. L.; KANEKO, T. M.; NISHIKAWA, S. O.; FREITAS, B. R. Métodos para avaliação da atividade antimicrobiana e determinação da concentração mínima inibitória (CMI) de plantas medicinais. Revista Brasileira de Farmacognosia, v. 18, n. 2, p. 301-307, 2008.

RAY, B. Fundamental food microbiology. Boca Raton: CRC Press, 2004. 608 p.

RAZAVI ROHANI, S. M.; MORADI, M.; MEHDIZADEH, T.; SAEI-DEHKORDI, S. S.; GRIFFITHS, M. W. The effect of nisin and garlic (Allium sativum L.) essential oil separately and in combination on the growth of Listeria monocytogenes. Food Science and Technology, v. 44, n. 10, p. 2260-2265, 2011.

RODRIGUES, L.; BANAT, I. M.; TEIXEIRA, J.; OLIVEIRA, R. Biosurfactants: potential applications in medicine. Journal of Antimicrobial Chemotherapy, v. 57, n. 4, p. 609-618, 2006.

RUFINO, R. D.; LUNA, J. M.; SARUBBO, L. A.; RODRIGUES, L. R. M.; TEIXEIRA, J. A. C.; CAMPOS-TAKAKI, G. M. Antimicrobial and anti-adhesive potential of a biosurfactant Rufisan produced by Candida lipolytical UCP 0988. Colloids and Surfaces B: Biointerfaces, v. 84, n. 1, p. 1-5, 2011.

RUHR E.; SAHL, H. G. Mode of action of the peptide antibiotic nisin and influence on the membrane potential of whole cells and on cytoplasmic and artificial membrane vesicles. Antimicrobial Agents and Chemotherapy, v.27, n. 5, p. 841-845, 1985. 
SÁNCHEZ, M.; TERUEL, J. A.; ESPUNY, M. J.; MARQUÉS, A.; ARANDA, F. J.; MANRESA, A.; ORTIZ, A. Modulation of the physical properties of dielaidoylphosphatidylethanolamine membranes by a dirhamnolipid biosurfactant produced by Pseudomonas aeruginosa. Chemistry and Physics of Lipids, v. 142, n. 1-2, p. 118-127, 2006.

SÁNCHEZ, M.; ARANDA, F. J.; TERUEL, J. A.; ESPUNY, M.J.; MARQUÉS, A.; MANRESA, A.; ORTIZ, A. Permeabilization of biological and artificial membranes by a bacterial dirhamnolipid produced by Pseudomonas aeruginosa. Journal of Colloid and Interface Science, v. 341, n. 2, p. 240-247, 2010.

SCHULZ, D.; PEREIRA, M. A.; BONELLI, R. R.; NUNES, M. M.; BATISTA, C. R. V. Bacteriocinas: mecanismo de ação e uso na conservação de alimentos. Alimentos e Nutrição, v. 14, n. 2, p. 229-235, 2003.

SINGH, P. K.; TACK, B. F.; McCRAY, P. J. R.; WELSH, M. J. Synergistic and additive killing by antimicrobial factors found in human airway surface liquid.

American Journal of Physiology - Lung Cellular and Molecular Physiology, v. 279, n. 5, p. L799-L805, 2000.

SINGH, B.; BERNADETTE, F. M.; ADAMS, M. R. Synergistic inhibition of Listeria monocytogenes by nisin and garlic extract. Food Microbiology, v. 18, n. 2, p. 133139, 2001.

SINGH, P.; CAMEOTRA, S. S. Potential applications of microbial surfactants in biomedical sciences. Trends in Biotechnology, v. 22, n. 3, p. 142-146, 2004.

SOTIROVA, A. V.; SPASOVA, D. I.; GALABOVA, D. N.; KARPENKO, E.; SHULGA, A. Rhamnolipid-biosurfactant permeabilizing effects on gram-positive and gramnegative bacterial strains. Current Microbiology, v. 56, n. 6, p. 639-644, 2008.

SZABO, E. A.; CAHILL, M. E. The combined affects of modified atmosphere, temperature, nisin TM and ALTA 2341 on the growth of Listeria monocytogenes International Journal of Food Microbiology, v. 43, n. 1-2, p. 21-31, 1998.

THOMAS, L. V.; DAVIES, E. A.; DELVES-BROUGHTON, J.; WIMPENNY, J. W. Synergist effect of sucrose fatty acid esters on nisin inhibition of gram-positive bacteria. Journal Applied Microbiology, v. 85, n. 6, p. 1013-1022, 1998. TONG, Z.; DONG, L.; ZHOU, L.; TAO, R.; NI, L. Nisin inhibits dental cariesassociated microorganism in vitro. Peptides, v. 31, n. 11, p. 2003-2008, 2010. 
TORTORA, G. J.; FUNKE, B. R.; CASE, C. L. Microbiologia, 8ee Porto Alegre: Artmed, 2005. 894 p.

VERHEUL, A.; RUSSELL, N. J.; VAN'T HOF, R.; ROMBOUTS, F. M. ABEE, T. Modifications of membrane phospholipid composition in nisin-resistant Listeria monocytogenes Scott A. Applied and Environmental Microbiology, v. 63, n. 9, p. 3451-3457, 1997.

VERMA, P. Methods for determining bactericidal activity and antimicrobial interactions: synergy testing, time-kill curves, and population analysis. In SCHWALBE, R.; STEELE-MOORE, L.; GOODWIN, A. C. (Ed.). Antimicrobial susceptibility testing protocols. Boca Raton: Taylor \& Francis, 2007. p. 275-299

WEIMER, B. C. Compositions and methods for using syringopeptin 25A and rhamnolipid. US2008261891-A1, 23 oct. 2008.

WHITE, D. G.; ZHAO, S.; SIMJEE, S.; WAGNER, D. D.; MCDERMOTT, P. F. Antimicrobial resistance of foodborne pathogens. Microbes and Infection, v. 4, n. 4, p. 405-412, 2002.

WOODS, G. L.; WASHINGTON, J. A. Antibacterial susceptibility tests: dilution and disk difusion methods. In: Manual of clinical microbiology. Washington: ASM Press, 1995. p.1327-1341. 